\title{
Exemplifying the Effects Using WetSpass Model Depicting the Landscape Modifications on Long-Term Surface and Subsurface Hydrological Water Balance in Bilate Basin, Ethiopia
}

\author{
Abera Shigute Nannawo $\left(\mathbb{D}\right.$, Tarun Kumar Lohani ${ }^{(D)}$, and Abunu Atlabachew Eshete \\ Arba Minch Water Technology Institute, Arba Minch University, Arba Minch, Ethiopia \\ Correspondence should be addressed to Abera Shigute Nannawo; aberashigute@gmail.com
}

Received 24 May 2021; Accepted 16 August 2021; Published 10 September 2021

Academic Editor: Mosbeh Kaloop

Copyright (C) 2021 Abera Shigute Nannawo et al. This is an open access article distributed under the Creative Commons Attribution License, which permits unrestricted use, distribution, and reproduction in any medium, provided the original work is properly cited.

\begin{abstract}
The alteration of spatial patterns of landscape interrupts water balance components in Bilate basin of Ethiopia. The aim is to characterize the spatio-temporal variation of surface-subsurface hydrological water balance using the WetSpass model comprising of soil type, topography, groundwater depth, and slope. Environment for Visualizing Images (ENVI) and Arc-GIS software were assimilated for the classification of Landsat images from 1989 to 2019 replicating the forest, shrub, and grasslands which decrease by $4.0 \%, 9.41 \%$, and $14.87 \%$, respectively, and agricultural land increasing by $27.06 \%$ from 1989 to 2019 . The goodness of fit in surface runoff and subsurface flow for the two model outputs with the square of regression $\left(R^{2}\right)$ of 0.79 and 0.81 , while the root mean square errors (RMSEs) $8.26 \mathrm{~mm}$ and $8.39 \mathrm{~mm}$ for 1989 and 2019, respectively, were calculated. Average annual interception, groundwater recharge, surface runoff, and actual-evapotranspiration were $36.4 \mathrm{~mm}, 127.34 \mathrm{~mm}, 614.95 \mathrm{~mm}$, and $517.59 \mathrm{~mm}$, respectively, revealing that WetSpass works remarkably in simulating the components of the hydrological water balance.
\end{abstract}

\section{Introduction}

Water is important, limited, exposed, and valuable natural resource on the planet. Lack and scarcity of freshwater from the surface resources may enhance the use of exploiting groundwater in the coming years irrespective of the country or continent [1]. Ethiopia is predominantly covered with a mountainous topography, which relies on rainfall-runoff processes [2]. Though the country is known as the tower of Africa, rich in surface and groundwater resources fostered by 12 major river basins, 22 lakes, and other renewable sources [3], sporadic droughts, erosion, flooding, and drying of streams, springs, and lakes seem to be increasing [4] year after year. The hydrological cycle of the area is affected by sporadic change in infiltration, interception, runoff, and evapotranspiration (EVT) which is usually carried out by human activities changing the land surface [5]. Due to radical growth of population and high urbanization and dynamics of land use, surface runoff has been used imprudently [6]. Human interferences have been sensationally changing the land cover with a considerable impact on the soil, water, and atmosphere [7]. Ultimately, groundwater has become the alternate resource for sustaining agricultural, industrial, and domestic activities in many arid and semiarid regions [8]. In recent years, stresses on groundwater resources have been increasing due to economic development and massive population growth [9]. The recharge has been affected due to rainfall variability and land use land cover (LULC) change in due course of time [10]. The magnitude, shape, and distribution of the groundwater recharge, as well as surface runoff, are affected by changes in LULC [11]. Land-use change affects the infiltration potential and groundwater storage [12] as well.

In Bilate basin of Ethiopia, cultivated land and settlement area are impertinently increasing but simultaneously forest, shrub, and bushlands are declining [13]. In addition to this, the basin is characterized by low groundwater recharge relative to the surface runoff due to the effect of impermeable 
soils, the morphology of the land, and LULC [14]. Water balance describes tracking the equilibrium between flowing input/output the water of any hydrological system, and there exists various mechanisms for estimating magnitude and distribution of surface and subsurface water balance components which can be broadly classified into physical, chemical, tracer, and numerical modelling methods [15]. A well-tested physically based and spatially distributed hydrological water balance model normally used for analysing impacts of LULC on water balance components such as actual evapotranspiration, groundwater, interception, and surfacesubsurface water over the basin is WetSpass [16]. This model uses long-term average climatic data, together with topography, land cover, and soil mapping, to estimate average spatial patterns of surface runoff, EVT, and groundwater recharge and physically-based and spatially-distributed water balance to estimate groundwater recharge [17-20].

From the previous studies, it can be established that estimating the magnitude and distribution surface and subsurface hydrologic water balance under continuous modification of landscapes in the basin has been mistreated. Furthermore, it has not yet been evaluated using a physically-based and spatially-distributed water balance model with increasing LULC changes for the Bilate basin. Therefore, characterizing and examining the magnitude of surface and subsurface hydrologic water balance with the continuous influence of landscape modification is imperative for proposing an appropriate sustainable water resource management strategy of the basin. Groundwater recharge in the study area is vulnerable to LULC changes. Over the past few decades, rapid population growth has led to deforestation for the expansion of agricultural lands which caused unexpected depletion of the groundwater table. Till date, no such remarkable information regarding hydrologic water balance components of the basin is available. Most of the research focused only on determining the scale of LULC, and there are few studies that focused on its impact on water resources availability.

\section{Materials and Methods}

2.1. Study Area. The Bilate basin is located in the main Ethiopian rift valley lake basin lying between $6030^{\prime}-8010^{\prime} \mathrm{N}$ latitude and 370400-38020' E longitude, and its drainage area is about $5402.8 \mathrm{~km}^{2}$ (Figure 1) characterized by a semiarid climate in the lower part of the basin and dry humid to the humid climate in the central, north, and west highlands of the basin, such as the mountain area of Gurage, Hadiya, and Kembata zonal states. Haji et al. [21] verified that the basin is topographically can be divided into the rift, escarpment, and highland physiographic zone. Due to undulating topography that ranges from $1200 \mathrm{~m}$ above mean sea level (a.m.s.l) to $3200 \mathrm{~m}$ a.m.s.l, there is significant variability in mean annual rainfall in the basin. In lieu of the topography, the basin is classified into three subbasins; upper, middle, and lower with an average of $1165 \mathrm{~mm}$ of rainfall, and it has been recorded that the annual rainfall varies between 1280-1339, 1061-1516, and 769-956 $\mathrm{mm}$ in the upper, middle, and lower part of the basin, respectively [22]. The Bilate basin stretches $225 \mathrm{~km}$ southwards before joining Lake Abaya and covers Southern Nations Nationalities and Peoples' Region (SNNPR) which includes Hadiya, Kembata-Tambaro, Gurage, Silte, Wolaita, Alaba zones, Sidama regional states, and a small part of south-central Oromia regional state. Most of the perennial tributaries come from the north and western part of the study area, while the eastern region has low intensity due to intermittent streams.

Since Ethiopia is one of the mountainous countries in Africa, natural features play an imperative role in the agroecological zonation. Accordingly, the climate of Ethiopia is classified into six agroecological zones (AEZs) such as Wurch (extremely cold climate of more than 3700 m.a.s.l), High Dega (cold climate of 3200-3700 m.a.s.l), Dega (temperate like climate-highland with 2300-3200 m.a.s.l), Weyna Dega (warm climate with 1500-2300 m.a.s.l), Kola (hot and arid type with 500-1500 m.a.s.l), and Berha (hot and hyperarid type, $<500$ m.a.s.l) climate. According to this classification, the major part of the study area falls in Weyna Dega and Kola region.

\subsection{Water Balance Calculation Using WetSpass Model.} According to Batelaan et al., the spatially distributed water balance quasi-steady state WetSpass model that stands for water and energy transfer is applied to evaluate long-term mean spatial patterns of EVT, surface runoff, and groundwater recharge. They explored that the original WetSpass model is a quasi-steady state physically-based and spatially-distributed water balance model scripted in avenue and used to predict hydrological processes at seasonal and annual time step. The components of water balance of the vegetated, barren soil, open-water, and impervious fraction per raster cell were calculated using equations (1) to (3) [23], and the results were analyzed:

$$
\begin{gathered}
\mathrm{ET}_{\text {raster }}=a v \mathrm{ET}_{v}+a s E_{s}+a o E_{0}+a_{i} E_{i}, \\
S_{\text {raster }}=a v S_{v}+a s S_{s}+a o S_{o}+a_{i} S_{i}, \\
R_{\text {raster }}=a v R_{v}+a s R_{s}+a o R_{o}+a_{i} R_{i},
\end{gathered}
$$

where $\mathrm{ET}_{\text {raster }}=$ total evapotranspiration, $S_{\text {raster }}=$ surface runoff, $R_{\text {raster }}=$ groundwater recharge of a grid cell, " $v$ " designates vegetated, " $s$ " for barren soil, " $o$ " stands for open water, and " $i$ " for the impervious area.

The terms $a v, a s, a o$, and $a i$ are fractional areas of vegetated, barren soil, open water, and impervious area, respectively.

\subsection{The Input Data for WetSpass model. Estimating mag-} nitude and spatial distribution of groundwater recharge using the fully distributed WetSpass-M model was assimilated using ArcGIS that included land use, historical daily precipitation, potential evapotranspiration, minimum and maximum temperatures, daily discharge, wind speed, topography, slope, soil texture, and groundwater depth data [24]. Gridded maps such as land use, soil, slope, topography, groundwater depth, precipitation, potential 


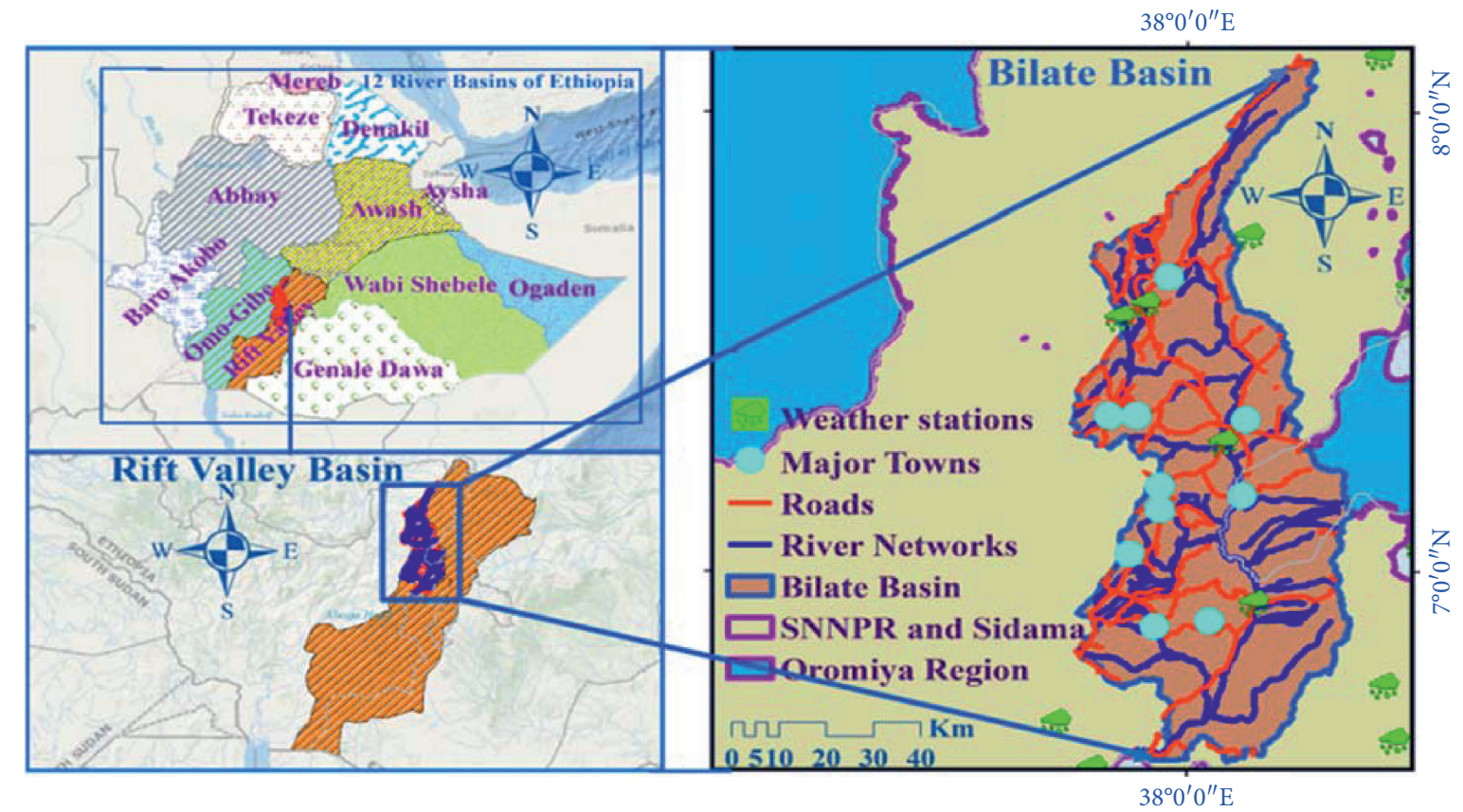

Figure 1: Map of the study area.

evapotranspiration, wind speed, and parameter tables are prepared in ArcGIS software tools that provided input for the WetSpass model. The cell size of the raster was $30 \mathrm{~m} \times 30 \mathrm{~m}$ with total number of $(1975,5635)$ raster cells. The Digital Elevation Model (DEM) with $30 \mathrm{~m}$ resolution and the elevation grid map at $30 \mathrm{~m}$ resolution was obtained from the elevation databases of the Advanced Spaceborne Thermal Emission and Reflection and Radiometer ASTER, the highest point of the study area was $3355 \mathrm{~m}$ in the northern part of Gurage mountains, and the lowest was $1116 \mathrm{~m}$ in the southern part of the area at the outlet of the basin. The slope map is derived from the DEM in ArcGIS, using the slope analysis tool. The slope varies from $0 \%$ to $216.8 \%$. Since Bilate basin lies in the bimodel climatic zone [25], four seasons such as winter, spring, summer, and autumn are considered for the study. Topography, slope, and soil type grid maps are characteristically nonseasonal that do not show variability in seasonal changes, whereas land use, precipitation, temperature, potential evapotranspiration, wind speed, and ground water depth are variable in nature with time are taken into account. The WetSpass model, the physically-based and fully-distributed model, was used to simulate the hydrological process under climate changes and in its variability in the watershed (Haile and Kassa) [26-29]. Therefore, in the current study, the detailed methodology (Figure 2) was utilized to estimate the exemplifying impact of landscape modification and climatological influences on the surface and subsurface water in Bilate basin of Ethiopia.

\subsubsection{Collecting Hydro-Meteorological Data and Processing} Analysis. Twelve selected meteorological stations' data including precipitation, minimum and maximum temperature, humidity, solar radiation, and wind speed were acquired from NMA. The existing discharge data of the major rivers which are recorded at gauging stations such as Alaba Kulito, Bilate Tena, Guder, Weira, and Batena stations data were obtained from Ministry of Water, Irrigation, and Energy (MoWIE) (Table 1).

2.4. Data Processing and Analysis. In order to understand detailed climatological distribution and spatio-temporal fluctuations in Bilate basin and assess their impacts on hydrologic water budget components, a hydrological WetSpass model is used. However, any simulation depends on the quality of the available data; in this study, data checking was made for their reliability. Statistical analysis of the daily data, monthly averages, and standard deviations was conducted.

2.4.1. Missing Weather Data and Quality Analysis. Missing data, lack of appropriate recording, shifting of station location, and processing may lead to incorrect and imprecise results that may contradict the actual situation. Therefore, in this study, the missing values for the rainfall data were filled using the second-degree inverse distance weighted (IDW) interpolation method, which is the most popular and simple method to fill the missing data of meteorological data among climatic researchers [30]. The consistency and homogeneity of rainfall data from individual stations were evaluated. Figure 3 shows homogeneity for the selected stations was tested by computing nondimensional resonate of rainfall data through dividing the monthly time seriel2s data via the average rainfall amount of the respective year. In most of the basin, the maximum rainfall exists between (March-May and July-September) and consistently shows bimodal rainfall distribution that can be homogeneous rainfall distribution throughout the basin.

Double mass curve (DMC) is one of the important techniques used to assess data consistency of some stations 


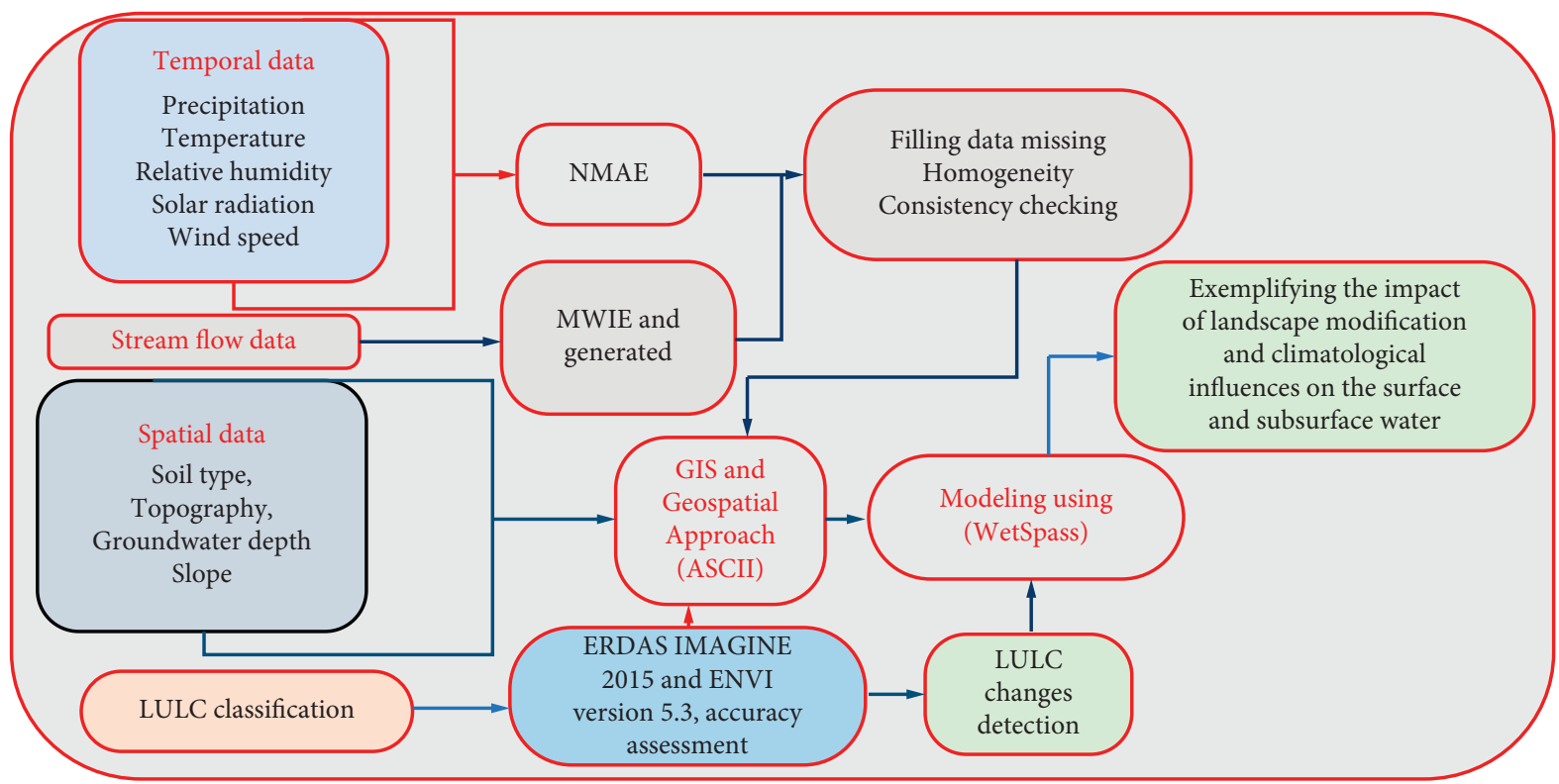

FIGURE 2: Flowchart methodology for exemplifying the impact of landscape modification and climatological influences on the surface and subsurface water.

TABle 1: Available meteorological stations within the study area.

\begin{tabular}{|c|c|c|c|c|c|c|}
\hline Sl. no. & Station name & Easting & Northing & Elevation & Types of climate data & Duration \\
\hline 1 & Alaba Kulito & 7.31 & 38.09 & 1772 & Partially all data types & 1988-2019 \\
\hline 2 & Hosanna & 7.56 & 37.85 & 2307 & All types of climate data & $1981-2019$ \\
\hline 3 & Hulbarag & 7.77 & 38.12 & 1996 & PCP, Tmax, and Tmin & 1986-2019 \\
\hline 4 & Durame & 7.2 & 37.95 & 2000 & PCP, Tmax, and Tmin & $1986-2019$ \\
\hline 5 & Angacha & 7.34 & 37.85 & 2317 & PCP, Tmax, and Tmin & 1988-2019 \\
\hline 6 & Boditi & 6.95 & 37.95 & 2043 & PCP, Tmax, and Tmin & $1981-2019$ \\
\hline 7 & Areka & 7.06 & 37.70 & 1752 & PCP & 1986-2019 \\
\hline 8 & Fonko & 7.65 & 37.95 & 2246 & PCP & 1986-2019 \\
\hline 9 & Wolaita Soddo & 6.81 & 37.73 & 1854 & Partially all data types & 1986-2019 \\
\hline 10 & Bilate Tena & 6.91 & 38.11 & 1496 & PCP, Tmax, and Tmin & 1988-2019 \\
\hline 11 & Shone & 7.13 & 37.95 & 1959 & PCP & 1986-2019 \\
\hline 12 & Bilate & 6.81 & 38.08 & 1361 & PCP, Tmax, and Tmin & 1986-2019 \\
\hline
\end{tabular}

PCP is precipitation; Tmax is maximum temperature; $T \mathrm{~min}$ is minimum temperature.

through comparative analyses [31]. Originally, it was developed to check the consistency of rainfall or precipitation records [32]. Furthermore, it is composed of cumulated values of a given station that are plotted against accumulated values of the average value of other stations, over the same period of time. Through the double-mass curve, inhomogeneities in the time series (in particular jumps) can be investigated, if for a change in observer record, in rain-gauge type, etc. The data series, which is inconsistent, can be adjusted to consistent values by proportionality. However, it can be seen illustrated that all the stations are consistent in this study area (Figure 4).

2.4.2. Generating Hydrometric Data for the Outlet of the Basin. Getting adequate and accurate inputs such as precipitation and streamflow data are important for successful hydrological modelling [33]. Hence, hydrometric data is one of the important input data in any hydrological modelling to evaluate the performance of the hydrological model through calibrating the outputs of the simulated value with the observed one. However, in many developing countries including Ethiopia, high-resolution hydrology and meteorological stations cannot be installed in remote locations due to financial and technical constraints. In this region runoff simulations, estimates in ungauged catchments (PUB) are the most significant and challenging issues for hydrologists. In Bilate river basin of Ethiopia, it is a difficult task to implement any hydrological model to predict the effects of human-induced and natural stress on surface and subsurface water resources and to produce appropriate water resources management strategies. This is because of the limited and sparsely installation of stream flow measuring stations over the basin. In order to solve such obstacles, researchers have been paid efforts through implementing multiple regionalization techniques worldwide. Therefore, regionalization is a technique to estimate the historic streamflow at the ungauged part of the watershed [34], through the process of transferring hydrometric information from gauged 


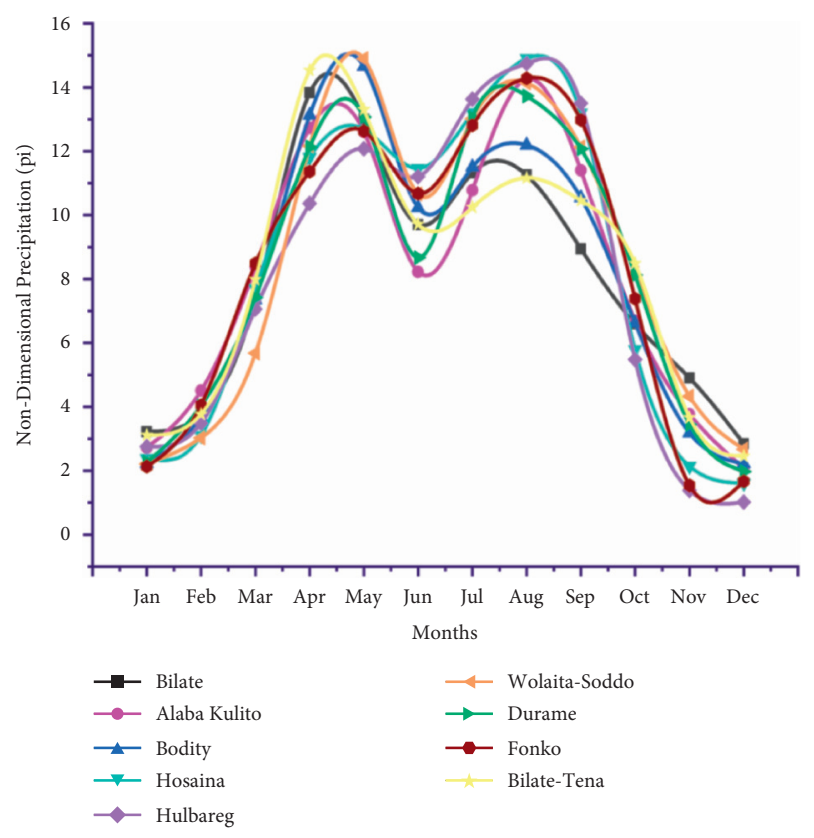

FIGURE 3: Homogeneity test of rainfall data.

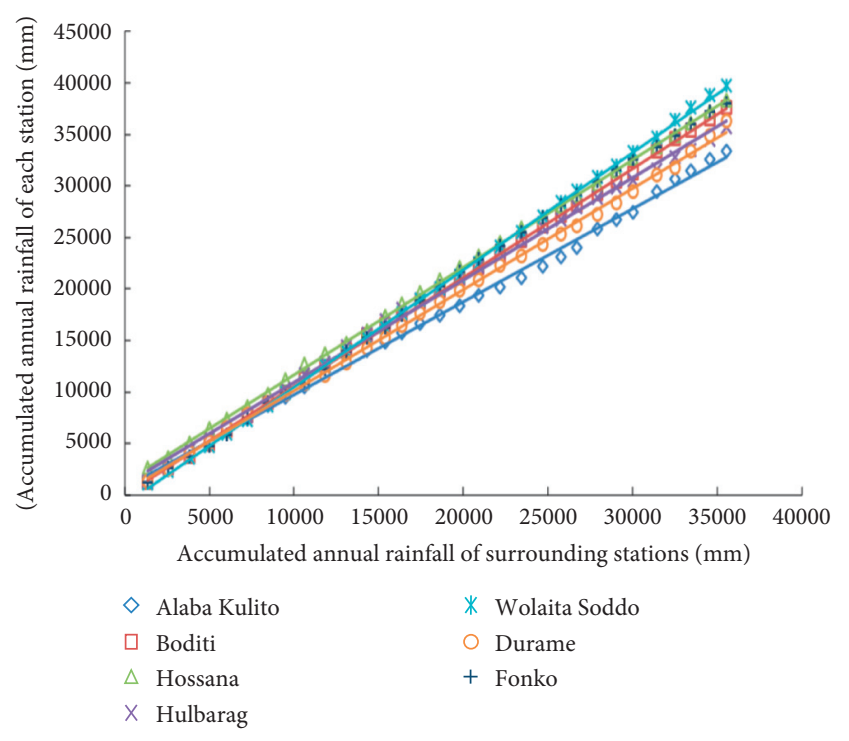

FIgURE 4: Consistency analysis using DMC.

(Donors) to ungauged catchments. In the past several decades, some regionalization techniques have been developed by different investigators to estimate noticeable streamflow at an area with sparsely or limited hydrometric data, for example, Arithmetic Mean (AM) [35-37], Physical Similarity (PS), [38-40] Spatial Proximity (SP) [37, 41, 42], Regression $(R)$ [37, 42-46], Catchment Runoff Response Similarity (CRRS), [47], and Probabilistic Random Forests (PRF) [48]. According to a comprehensive review of Gao et al. [31] in physical similarity and regression-based regionalization, a variety of remotely sensed based evidence such as land use and vegetation cover needs to be extracted from the catchment attributes for prediction of streamflow at ungauged catchments. Multiple linear regression (MLR) to be termed as a statistical technique which uses numerous descriptive variables to forecast the outcome of a response variable, and the process was used in generating flow in ungauged catchment to develop the linear relationship between the descriptive (independent) variables and response (dependent) variable. Therefore, Multiple Linear Regression (MLR) regionalization analysis was performed to generate the daily and monthly flow data for the ungauged outlet of the basin using the multiple regression equation via developing the relation between gauged and ungauged catchments:

$$
Y=\beta_{0}+X_{1} \beta_{1}+X_{2} \beta_{2}+X_{3} \beta_{3}+\cdots+X_{p-1} \beta_{p-1}+\varepsilon,
$$

where $Y$ is the predictable value of the $j$ th hydrological index, $X 1, X 2, \ldots, X_{p-1}$ is $p-1$ physical catchment property, $\beta 0, \beta 1$, $\beta 2, \ldots, \beta_{p-1}$ are the $p$ regression coefficients, and $\varepsilon$ is the random error term.

From the twelve discharge measuring stations, only six measuring stations are available within the Bilate basin, but the other six stations are obtained from MWIE of Ethiopia that are situated around Bilate basin specifically, Northern, West, and East of the basin (Tables 2 and 3). Availability and continuity trend of time series of the flow data was checked if there are discontinuities in the recordings. Some gauging stations have discontinuity problems after some years, for example, Batena and Gombora from 2005, Weira and Guder from 2008, and Rinzaf gauging station near Butajira from 2006.

Table 4 represents the detail structure of the study area comprising of soil, land use, DEM, and runoff coefficient for the study area.

2.4.3. Land Use/Land Cover Data. The land use/land cover maps were classified by using ENVI 5.3 for the collected remotely sensed data from Landsat sensor type of Landsat 5 Thematic Mapper (TM), Landsat 7 Enhanced Thematic Mapper Plus (ETM+), and Landsat 8 Operational Land Imager (OLI). Collected land-use data for 1989, 1999, 2009, and 2019 were retrieved from Landsat 5 TM, Landsat 7 ETM+, and Landsat OLI within (Path 168 and 169 and Row 054 and 055). The Digital Elevation Model (DEM) with $30 \mathrm{~m}$ resolution and the elevation grid map at $30 \mathrm{~m}$ resolution was obtained from the elevation databases of the ASTER; morphology and geology of the area were collected from the Ethiopian Geological Mapping Agency. To minimize the problem of cloud, all Landsat data was collected from January to March in identified periods. All the downloaded Landsat images were already geometrically corrected and georeferenced to the Universal Transverse Mercator (UTM) projection WGS84 zone $37 \mathrm{~N}$ within the geographic limit of $6030^{\prime}-8010^{\prime} \mathrm{N}$ latitude and $37040^{\prime}-38020^{\prime} \mathrm{E}$ longitude. After the required data are obtained, it was processed and classified using the maximum likelihood pixel-based supervised classification method in ENVI 5.3 software.

Accuracy assessment is known as a mechanism of the substantial step in the processing of image classification, and the overall accuracy is a comparison of the classified image with fixed land cover conditions collected from the 
TABLE 2: Available hydrological stations within and round the Bilate basin.

\begin{tabular}{|c|c|c|c|c|c|}
\hline Sl. no. & Station name & Easting & Northing & Temporal resolution & Duration \\
\hline 1 & Alaba Kulito & 7.17 & 38.04 & Daily & $1988-2016$ \\
\hline 2 & Bilate Tena & 6.56 & 38.08 & Daily & $1981-2017$ \\
\hline 3 & Weira & 7.35 & 37.55 & Daily & 1986-2008 \\
\hline 4 & Guder & 7.35 & 37.57 & Daily & 1986-2008 \\
\hline 5 & Batena & 8.35 & 37.57 & Daily & 1980-2005 \\
\hline 6 & Gombora & 7.33 & 37.52 & Daily & 1987-2004 \\
\hline 7 & Bedessa & 6.23 & 38.18 & Daily & $1982-2015$ \\
\hline 8 & Aletawondo & 6.38 & 38.24 & Daily & 1980-2010 \\
\hline 9 & Gidabo & 6.45 & 38.23 & Daily & 1976-2015 \\
\hline 10 & Hamassa & 6.40 & 37.40 & Daily & 1987-2015 \\
\hline 11 & Rinzaf & 8.07 & 38.22 & Daily & 1980-2007 \\
\hline 12 & Gelana & 6.09 & 38.11 & Daily & 1980-2015 \\
\hline
\end{tabular}

TABLE 3: Monthly generated flow using regression techniques.

\begin{tabular}{|c|c|c|c|c|c|c|c|c|c|c|c|}
\hline Jan & Feb & Mar & Apr & May & Jun & Jul & Aug & Sep & Oct & Nov & Dec \\
\hline 528 & 468 & 754 & 949 & 1578 & 1560 & 1853 & 2344 & 2326 & 2105 & 1327 & 847 \\
\hline
\end{tabular}

TABle 4: Available soil, land use, and DEM data within the study area.

\begin{tabular}{lccc}
\hline ID & Input data & Sources & Resolution \\
\hline 1 & Soil texture & (https://www.africover.org./index.htm) & $30 \times 30 \mathrm{~m}$ \\
2 & DEM (topography and slope) & https://gdex.cr.usgs.gov/gdex/ & $30 \times 30 \mathrm{~m}$ \\
3 & Land use land cover (summer and winter) & https://www.earthexplorer.usgs.gov/ & $30 \times 30 \mathrm{~m}$ \\
4 & Soil parameter look up table & From WetSpass user guide literatures & - \\
5 & Runoff coefficient look up table & From WetSpass user guide literatures & - \\
\hline
\end{tabular}

referenced locations (Table 5). Producer's accuracy calculates errors of omission, which is an amount of how actual land cover classes can be classified. User's accuracy evaluates errors of commission (inclusion), which characterizes the likelihood of a classified pixel corresponding to the land cover classes of its matching referenced location [49-51]. Therefore, the error matrix and kappa coefficient have developed a standard ways of accuracy validation of image classification.

Kappa statistic, evaluated as $k$, is as follows:

$$
\operatorname{Kappa}(k)=\frac{P o-P c}{1-P c},
$$

where $P o=\sum P i i$ is the sum of relative frequency in the diagonal of the actual error matrix and $P c=\sum P i+P+j$ is the relative frequency of a random allocation of observations to the cells chance agreement. The notations " $i+$ " and " $+j$ " stand for the relative marginal frequencies. Observed accuracy - chance agreement/1 - chance agreement. If the Kappa coefficient is 0 , it indicates an absolute disagreement between the map and the truth, and if it is 1 , it shows complete agreement [52].

2.4.4. Soil Types. Soil map of the Bilate basin extracted from available harmonized database of FAO, 1998 [53] (Figure 5). Soil type classes were translated into USGS soil texture classes, using the topsoil percentages of particle size fractions in order to make the data compatible to model requirement by using hydraulic properties calculator of soil water characteristics tool. The converted soil textural map shows loam $\quad 43.25 \% \quad\left(2336.89 \mathrm{~km}^{2}\right)$, sandy loam $41.56 \%$ $\left(2245.57 \mathrm{~km}^{2}\right)$, clayey sand $15.08 \%\left(815.21 \mathrm{~km}^{2}\right)$, and loamy sand $5.11 \%\left(1.09 \mathrm{~km}^{2}\right)$ of the basin.

2.4.5. Precipitation. Rainfall is considered as input for the water balance model, while evapotranspiration is considered as an output component [54]. Statistical parameters for a 31year time period were studied (1988-2019) with mean annual rainfall varied between $801.9 \mathrm{~mm}$ in the most southern part of the basin and $1406.5 \mathrm{~mm}$ in the central and northwest of the study area. The annual standard deviation of precipitation varied between 169.8 and 350.6, and mean annual variation of rainfall over the entire river basin was $20.2 \%$.

2.4.6. Estimation of Potential Evapotranspiration (PET). PET is one of the important inputs for the WetSpass model $[26,28,29,54]$. In order to estimate the potential evapotranspiration using Penman-Monteith methods, enough climatic data, such as mean air temperature, maximum air temperature, minimum air temperature, relative humidity, downward long-wave radiation flux, downward short-wave radiation flux, upward long wave radiation flux, upward shortwave radiation flux, wind, sunshine hour, and altitude (elevation), are required [55]. Hargreaves et al. [56] derived a 
TABle 5: Accuracy assessment of LULC classes.

\begin{tabular}{|c|c|c|c|c|c|c|c|c|c|}
\hline Class type & Waterbody & Settlement & Agricultural land & Forest & Shrub land & Grass land & Barren land & Row total & Accuracy \\
\hline Water body & 87 & 2 & 0 & 0 & 9 & 0 & 1 & 99 & 87.9 \\
\hline Settlement & 1 & 39 & 0 & 0 & 0 & 0 & 3 & 43 & 90.7 \\
\hline Agricultural land & 0 & 0 & 76 & 7 & 0 & 0 & 0 & 83 & 91.6 \\
\hline Forest & 1 & 1 & 1 & 29 & 0 & 0 & 0 & 32 & 90.6 \\
\hline Shrub land & 12 & 0 & 0 & 0 & 67 & 3 & 0 & 82 & 81.7 \\
\hline Grass land & 0 & 0 & 0 & 0 & 7 & 47 & 0 & 54 & 87.0 \\
\hline Barren land & 5 & 3 & 0 & 0 & 0 & 0 & 31 & 39 & 79.5 \\
\hline Row total & 106 & 45 & 77 & 36 & 83 & 50 & 35 & 432 & \\
\hline Accuracy & 82.1 & 86.7 & 98.7 & 80.6 & 80.7 & 94.0 & 88.6 & & \\
\hline
\end{tabular}

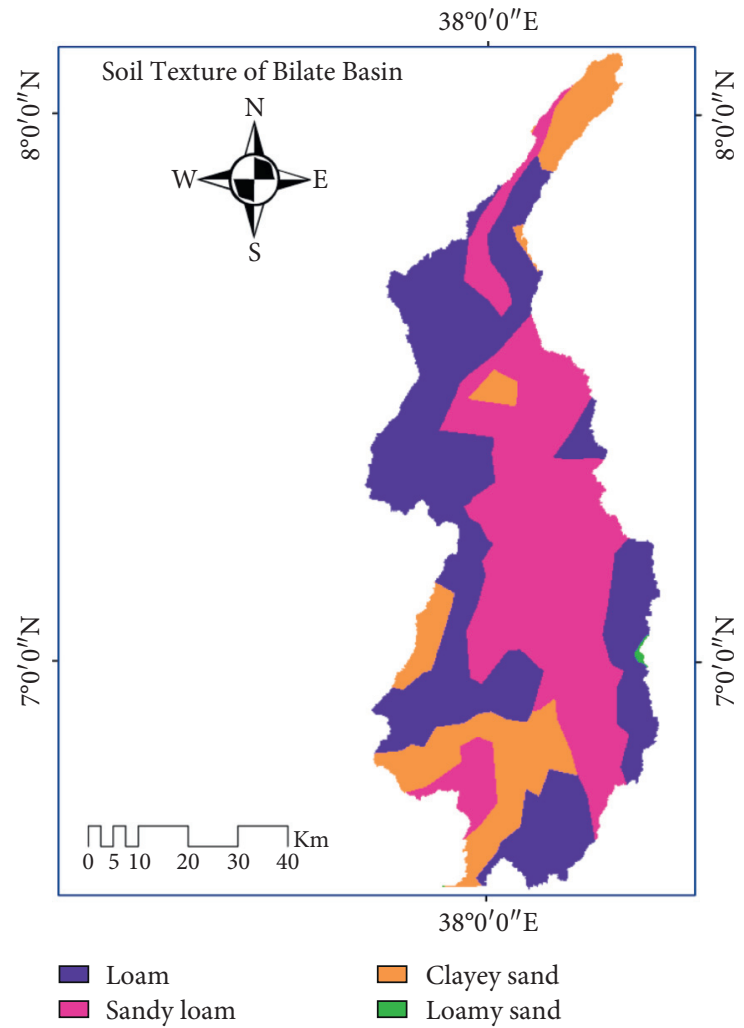

FIGURE 5: Soil map of Bilate basin.

function to estimate evapotranspiration in any area with only available mean daily maximum and mean daily minimum temperature and lack of reliable meteorological, such as relative humidity, wind speed, and solar radiation. Except Hosanna, Alaba Kulito and Soddo meteorological stations, the rest provide insufficient parameters, such as relative humidity, wind speed, and solar radiation. Therefore, evapotranspiration was calculated integrating Penman-Monteith methods for the stations with full available data and Hargreaves equations (equation (6)) in support of the mean daily minimum and mean maximum temperature and extraterrestrial radiation, and the estimated evapotranspiration was used as an input for the WetSpass model [57]:

$$
\mathrm{PET}=0.0023\left(T_{\text {mean }}+17.8\right)\left(T_{\max }-T_{\text {min }}\right) \times 0.5 R_{a},
$$

where $\mathrm{PET}=$ the potential evapotranspiration $(\mathrm{mm} /$ day $)$, $T_{\text {max }}, T_{\text {min }}$, and $T_{\text {mean }}$ are maximum, minimum, and average temperature $(\mathrm{C} 0)$, respectively, and $R_{\mathrm{a}}$ is extraterrestrial radiation ( $\mathrm{mm} /$ day).

The corrected average daily PET, precipitation, and observed stream discharge were provided as an input for the WetSpass model to simulate the water balance processes and evaluate the magnitude and distributed groundwater recharge value under LULC and changes in climate in the Bilate subbasin.

\section{Results}

3.1. LULC Classification Accuracy Assessment. The intensive field survey was carried out over the Bilate basin using the Global Positioning System (GPS). The preprocessing and classification of satellite imagery were conducted using ArcGIS and ENVI software. 699 Ground Control Points (GCP) embracing 93 water bodies, 82 settlements, 127 agricultural lands, 109 forests, 104 shrublands, 94 grasslands, and 90 barren lands were collected from various sources and applied to attain accurate site for different LULC class and were used for classifying structure as well as for the creation of training sites and signature generation. From the collected data, $419(60 \%)$ training points have been used for the training model and 280 (40\%) established as validation. Based on ground truth and image analysis, seven major LULC classes, such as open water, settlement, agricultural land, forest land, shrubland, grassland, and barren land, were identified for mapping the entire basin area (Table 6 and Figure 6). A vector layer is digitized over the raster scene in the study area containing various polygons overlaying different land use types. The training sites were used to produce spectral signatures for the delineated study area. Pixel-based supervised image classification with a maximum likelihood algorithm was applied to classify the images.

In the present study, the LULC types' confusion matrix was explored using ground validation points and Google Earth images to calculate the accuracy metrics, which stand for overall accuracy, omission, commission, and kappa coefficient. The determined result shows that the overall accuracy of the analysis of the LULC changes was above $87.8 \%$ and the overall kappa statistics were greater than 0.86 (Table 5).

The overall kappa statistics values reveal that the accuracy of the LULC classification is considerably good. The producers' accuracy ranged from $82 \%$ for barren lands to $92 \%$ for agricultural lands, and user's accuracy ranged from $85 \%$ for forest and shrublands to $94 \%$ for agricultural lands (Table 7). 
TABLE 6: Details of land use land cover.

\begin{tabular}{|c|c|}
\hline LULC class & Description \\
\hline Open waters & Water passages such as rivers and streams, and open water bodies such as lakes and ponds \\
\hline Settlement & $\begin{array}{c}\text { Areas covered with buildings either in rural and urban; it contains commercial, residential, industrial, and } \\
\text { transportation infrastructures }\end{array}$ \\
\hline $\begin{array}{l}\text { Agricultural } \\
\text { land }\end{array}$ & $\begin{array}{l}\text { All cultivated land, arable land fixed with rain-feed and irrigated crops, annual crops, and mixed with permanent crops } \\
\text { and some woody vegetation, orchards, groves, vineyards, nurseries and horticultural areas }\end{array}$ \\
\hline Forests & $\begin{array}{c}\text { All type of forests and woodland, including eucalyptus trees, deciduous forest land, evergreen forest land, and mixed } \\
\text { forest land }\end{array}$ \\
\hline Shrub land & $\begin{array}{c}\text { Bush or shrub-dominated land with isolated trees always with a lower range of grass and mainly wild shrubs, both } \\
\text { indigenous and extraterrestrial }\end{array}$ \\
\hline Grass & Grassland with low productivity often situated in plains, rough ground, or rocky areas \\
\hline Barren land & Areas with little or no "green" vegetation present due to erosion, overgrazing, and excavated for mining \\
\hline
\end{tabular}

$38^{\circ} 0^{\prime} 0^{\prime \prime} \mathrm{E}$

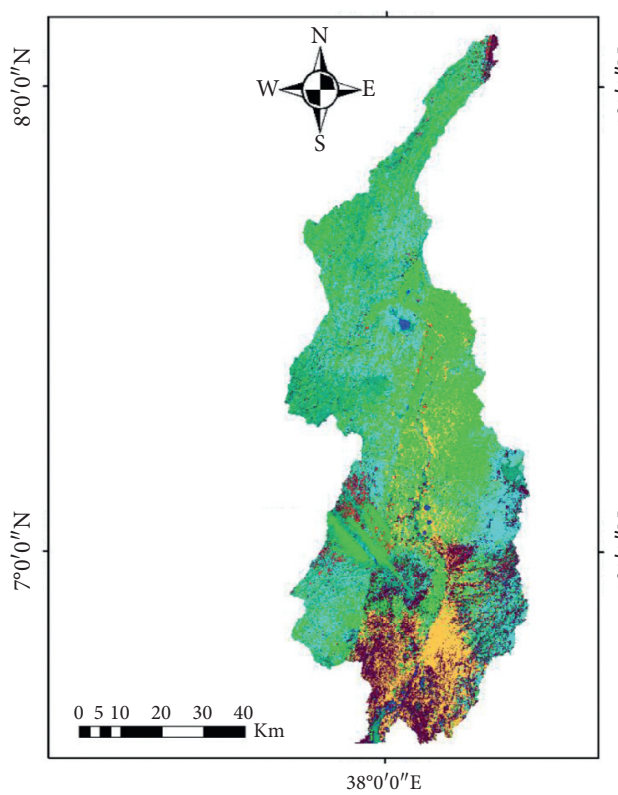

LULC-1989

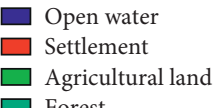
$\square$ Forest
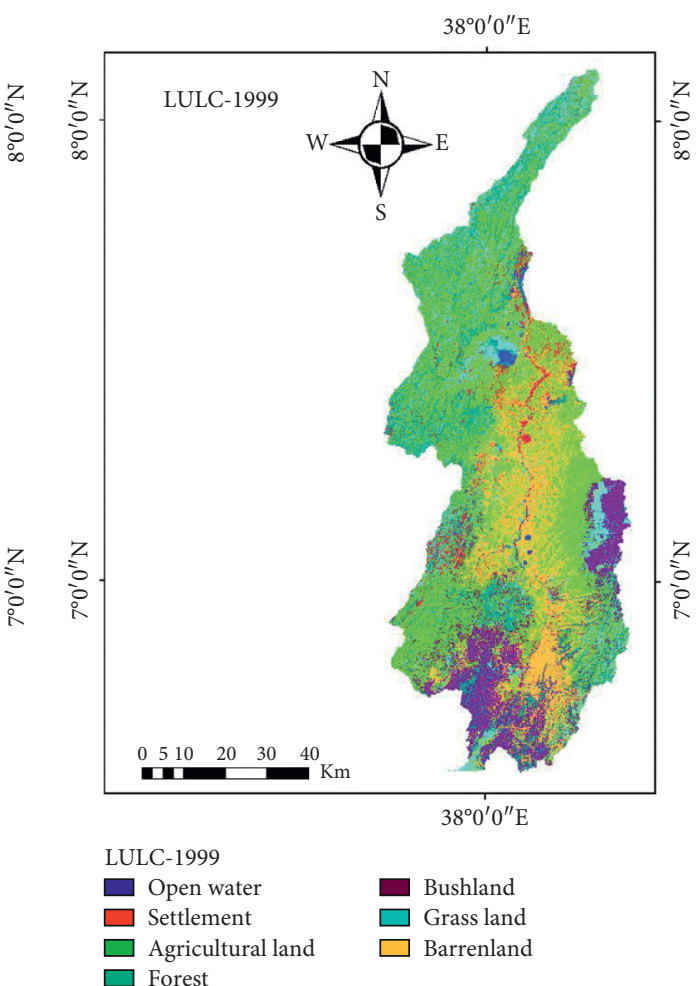

(b)

FIgURE 6: Continued. 


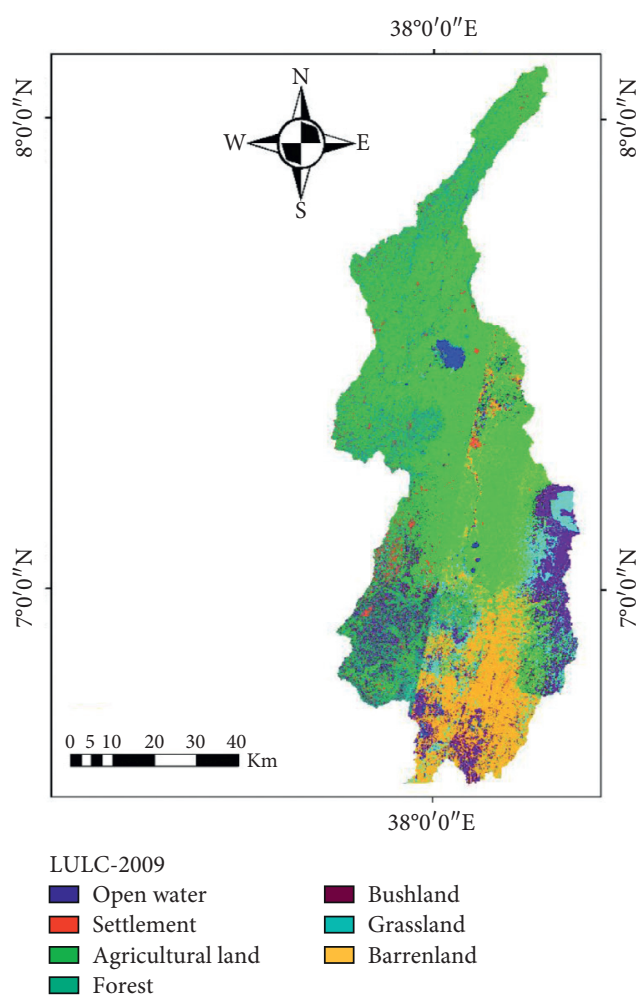

(c)

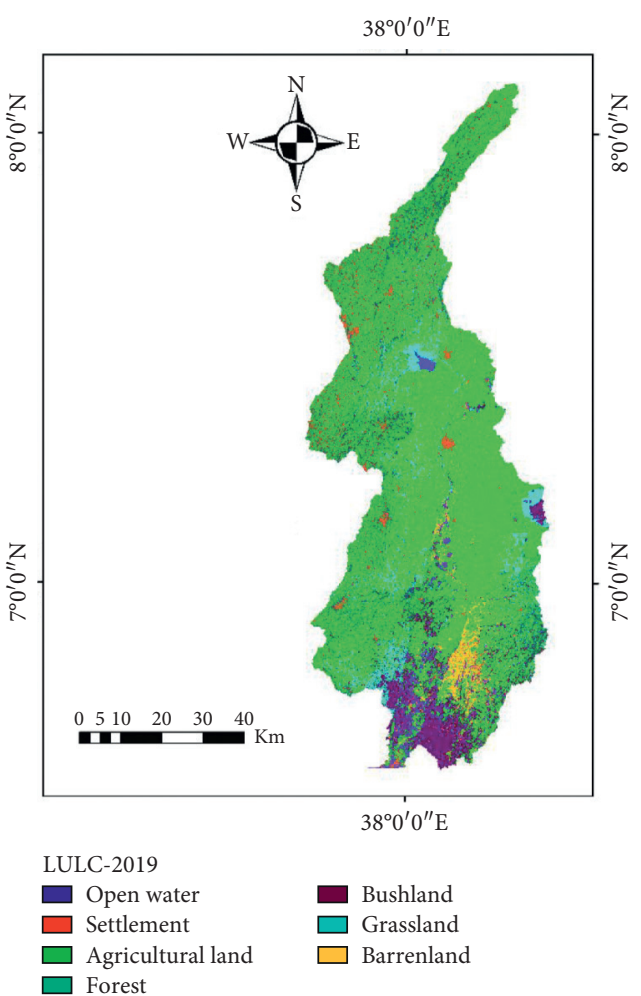

(d)

Figure 6: LANDSAT imagery classified land use maps of the basin for 1989, 1999, 2009, and 2019 (a, b, c, and d, respectively).

TABLE 7: Overall kappa statistics and accuracy for 1989, 1999, 2009, and 2019 LULC maps.

\begin{tabular}{lllll}
\hline Category & 1989 & 1999 & 2009 & 2019 \\
\hline Overall kappa statistics & 0.85 & 0.83 & 0.92 & 0.85 \\
Overall accuracy (\%) & 80.5 & 89.6 & 91.4 & 89.8 \\
\hline
\end{tabular}

3.2. LULC Changes. The land use maps for 1989, 1999, 2009, and 2019 for the Bilate basin (Figure 6). The seven land-use classes, such as open water, settlement, agriculture, forest, shrubland, grassland, and barren land, in the study area were incorporated. The results highlighted that the Bilate basin land use land cover is dominated by agricultural lands (Figures 7(a) and 7(b)). The overall agricultural land is more than $60 \%$ of the total area of the basin while the open water and barren land area are less than $10 \%$ of the total area in 2019 (Figure 7(b); Table 8). Due to the massive growth of population as stated by Jinno et al. [6], settlement and agricultural land showed noticeably increasing trends from $5.9 \%\left(318.6 \mathrm{~km}^{2}\right)$ to $8.3 \%\left(450.1 \mathrm{~km}^{2}\right)$ and $33.7 \%\left(1824 \mathrm{~km}^{2}\right)$ to $60.8 \%\left(3286.2 \mathrm{~km}^{2}\right)$, respectively, whereas the grassland, shrubland, and forest exhibited a decreasing trend from $21.8 \%\left(1181 \mathrm{~km}^{2}\right)$ to $6.9 \%\left(377.4 \mathrm{~km}^{2}\right), 15.81 \%\left(853.9 \mathrm{~km}^{2}\right)$ to $6.4 \%\left(1181 \mathrm{~km}^{2}\right)$, and $13 \%\left(853.9 \mathrm{~km}^{2}\right)$ to $9.1 \%\left(345.3 \mathrm{~km}^{2}\right)$ between 1989 and 2019 (Table 8 and Figures $7(\mathrm{a})$ and $7(\mathrm{~d})$ ). However, in the period of first 10 years (1989-1999), agricultural land and barren lands increased by $14.8 \%$ $\left(801.6 \mathrm{~km}^{2}\right)$ and $6.77 \%\left(366.2 \mathrm{~km}^{2}\right)$, respectively, while grassland, forest, and shrublands have decreased in the basin. Open water bodies, specifically the size of the river, show insignificantly decreasing trends in the basin with below 1\% (1989 to 2019). The determined analysis show that the agricultural land increased by $27 \%\left(1462.2 \mathrm{~km}^{2}\right)$ from 1989 to 2019 in the study area. Settlement experienced moderately increasing trends in 31 years (1989 to 2019). Except rising of lakes level insignificantly such as rift valley basin of Ethiopia, open water, specifically the size of the streamflow, exhibited a decreasing trend in dry periods with below 1\% (1989 to 2019), but in wet season, open water such as river flow shows highly increasing trends with increasing surface runoff.

\subsection{Evaluating WetSpass Model Performance.} Conventionally, the calibration processes of the WetSpass distributed hydrologic water balance model were implemented through manual adjusting or modifying the model parameters existing in the WetSpass model within a given range of values. The objective function is typically the correlation of the coefficient of determination $R^{2}$ between the simulated surface runoff and observed discharge. The adjusted parameters include alfa coefficient, " $a$ " interception, Lp coefficient, and runoff delay factor " $x$." These 


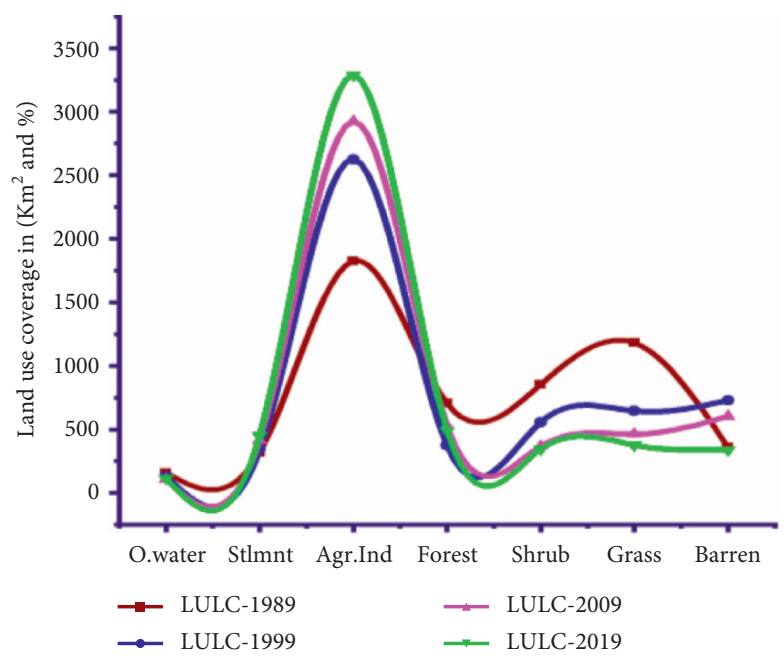

(a)

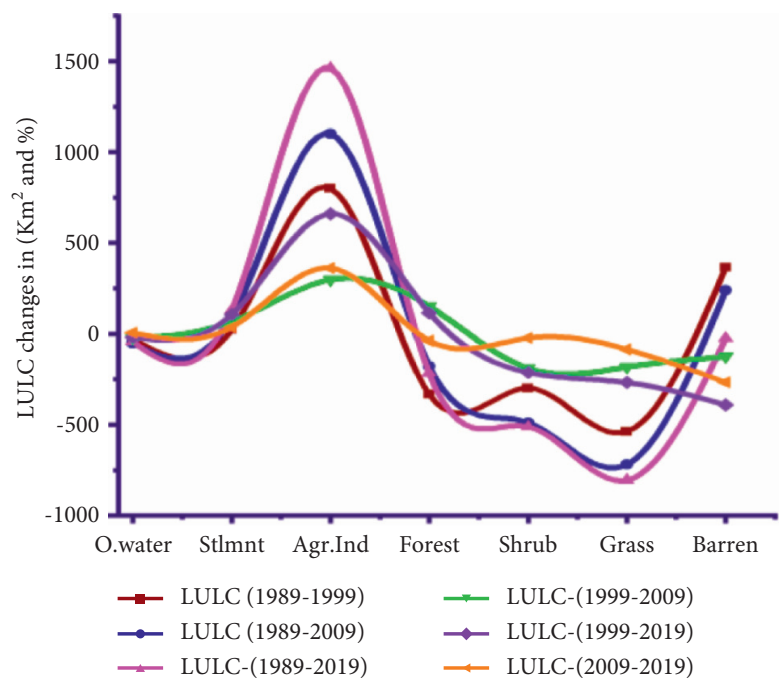

(c)

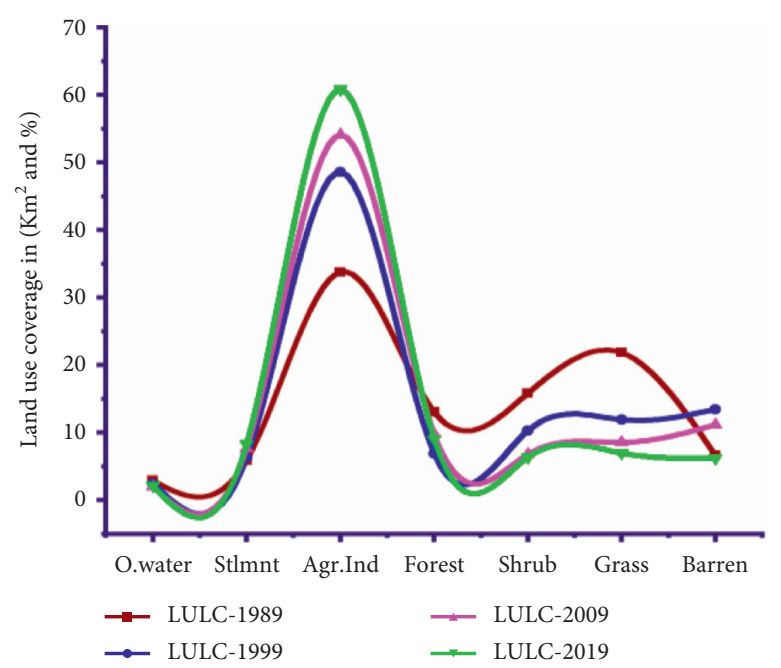

(b)

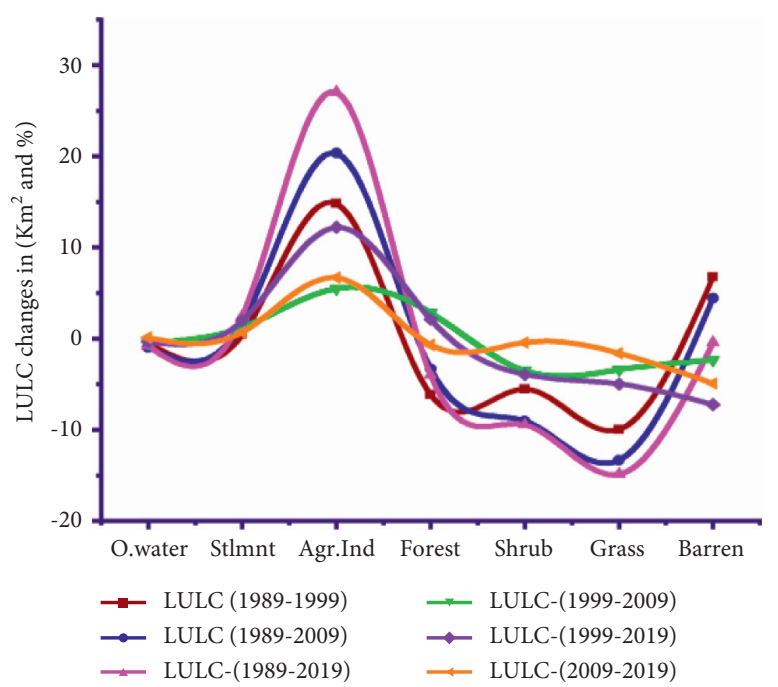

(d)

Figure 7: Land use coverage and magnitude of changes in $\mathrm{km}^{2}$ and \%. (a) Land use coverage in $\mathrm{km}^{2}$. (b) Land use coverage in \%. (c) Land use changes in $\mathrm{km}^{2}$ and land use changes in \%.

TABLE 8: Land use coverage in kilometres square $\left(\mathrm{km}^{2}\right)$ and percentage (\%).

\begin{tabular}{|c|c|c|c|c|c|c|c|c|}
\hline \multirow{2}{*}{ LULC } & \multicolumn{2}{|c|}{1989} & \multicolumn{2}{|c|}{1999} & \multicolumn{2}{|c|}{2009} & \multicolumn{2}{|c|}{2019} \\
\hline & Area $\left(\mathrm{km}^{2}\right)$ & $\%$ & Area $\left(\mathrm{km}^{2}\right)$ & $\%$ & Area $\left(\mathrm{km}^{2}\right)$ & $\%$ & Area $\left(\mathrm{km}^{2}\right)$ & $\%$ \\
\hline Open water & 158.2 & 2.9 & 131.9 & 2.4 & 108.0 & 2.0 & 115.3 & 2.1 \\
\hline Settlement & 318.6 & 5.9 & 342.9 & 6.4 & 411.4 & 7.6 & 450.1 & 8.3 \\
\hline Agriculture & 1824.0 & 33.8 & 2625.7 & 48.6 & 2923.8 & 54.1 & 3286.3 & 60.8 \\
\hline Forest & 705.9 & 13.1 & 374.0 & 6.9 & 527.4 & 9.8 & 490.7 & 9.1 \\
\hline Shrub land & 854.0 & 15.8 & 556.3 & 10.3 & 367.0 & 6.8 & 345.4 & 6.4 \\
\hline Grass land & 1181.0 & 21.9 & 644.5 & 11.9 & 462.7 & 8.6 & 377.5 & 7.0 \\
\hline Barren land & 361.2 & 6.7 & 727.4 & 13.5 & 602.6 & 11.1 & 337.7 & 6.3 \\
\hline
\end{tabular}

parameters were held in reserve optimizing up to the attainment of a final agreement between the calculated against observed discharge recorded at Bilate river and base flow obtained from separating the observed discharge using base flow separator techniques. The total flow in a river from a basin is a function of surface runoff and subsurface flow that is equivalent to the long-term mean seasonal river discharge from the basin [58]. The summation of subsurface flow and surface runoff simulated by the WetSpass model was implemented to calibrate the model with in situ observed streamflow data obtained from Bilate river gauge stations. Figure 8 shows that the simulation analysis has attained 


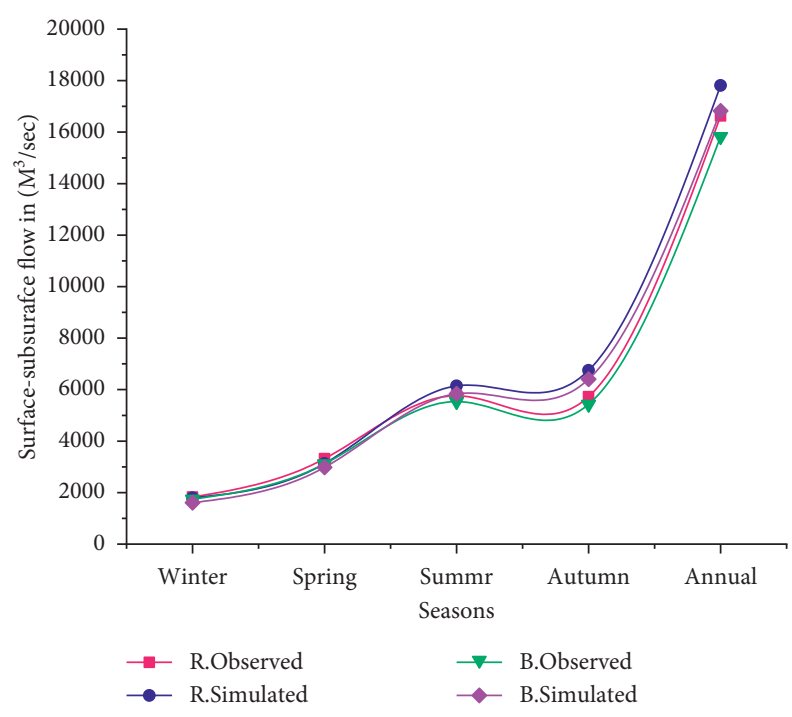

FIGURE 8: Compression between simulated surface flow and observed flow data, and estimated base flow against simulated subsurface.

excellently with a correlation coefficient of the "line of the goodness of fit" of 0.79 and 0.81 , respectively, with a standard error of 0.21 and 0.30 . Calibration of the WetSpass$\mathrm{M}$ model showed representative results for the total discharge and good results for the base flows. The verified model result shows that the mean minimum and maximum seasonal surface runoff in Bilate basin fluctuates from $13.3 \mathrm{~mm}$ to $309.4 \mathrm{~mm}$ in winter and summer in between (1989 to 2019), respectively. The thirty-one years' average minimum and maximum annual surface-runoff values are ranging from $606.2 \mathrm{~mm}$ to $642.4 \mathrm{~mm}$ in winter and summer, respectively.

3.3.1. Simulated EVT, Interception, Recharge, and Surface Runoff. The seasonal (Winter, Spring, Summer, and Autumn) and annual groundwater recharge, surface runoff, EVT, and an interception within the interval of each ten years' period 1989, 1999, 2009, and 2019 water balance components of land use classes were simulated using distributed hydrologic water balance WetSpass-M in the Bilate basin. The months DJF (December, January, and February), MAM (March, April, and May), JJA (June, July, and August), and SON (September, October, and November) are considered as winter, spring, summer, and autumn seasons, respectively. The summer and spring seasons are often known as wet seasons and contribute $35.4 \%(406.8 \mathrm{~mm}$ ) and $30.2 \%$ ( $346.1 \mathrm{~mm}$ ) of annual rain, respectively. Except for the northwest part of the basin near Angacha town, the winter season is almost remaining dry. There are increasing trends in each seasonal and annual water balance components such as surface runoff and EVT, while groundwater recharge exhibited decreasing trends when time goes up (Figure 9). In Ethiopia, extreme meteorological drought was recorded 2008-2009 [58]. The analysis results indicated that there are changes in water balance components with decreasing and increasing amounts for LULC classes of 2009. During this period, the average seasonal and annual water budget components such as interception, groundwater recharge, EVT, and surface runoff results shown are reduced compared to 1999 and 2019. Hence, simulation results were highly correlated with findings [21].

3.3.2. Simulated Seasonal and Annual EVT. The predicted spatial distribution of seasonal (winter, spring, summer, and autumn) and annual EVT was simulated by the WetSpass-M water balance model in the Bilate basin. The simulated result shows that the long-term mean seasonal minimum EVT of the basin is $75.6 \mathrm{~mm}$ which is recorded in the winter season for the land use map of 2009 in Table 9. The highest mean annual simulated value is $517.6 \mathrm{~mm}$ for the land use map of 1989. High annual and seasonal EVT are exhibited in the north western and some central areas of the basin where a high amount of precipitation has been recorded, while the south-east part, which receives less precipitation, has a lower EVT (Figure 10(a) and Table 9).

3.3.3. Simulated Seasonal and Annual Interception. Human activities on land surface are the typical reason for landscape modification in the Bilate basin. Consequently, the magnitude of infiltration, interception, runoff, and evapotranspiration are becoming changed obviously in the present study area (Figure 10(a) and Table 10). With this consent, our current investigated results of the simulated mean minimum and mean maximum seasonal interceptions in Bilate basin were $11.7 \mathrm{~mm}$ and $27.3 \mathrm{~mm}$ recorded in winter for the land use map of 2019 and in summer for land use map of 1989 , respectively.

3.3.4. Simulated Seasonal and Annual Surface Runoff. The determined results shows that the surface runoff is highly dependent on changes in the landscape in the Bilate basin (Figure 11(a) and in Table 11). Deforestation has become a continuous process, and successively, the forest lands are converted to agricultural land resulting in more 

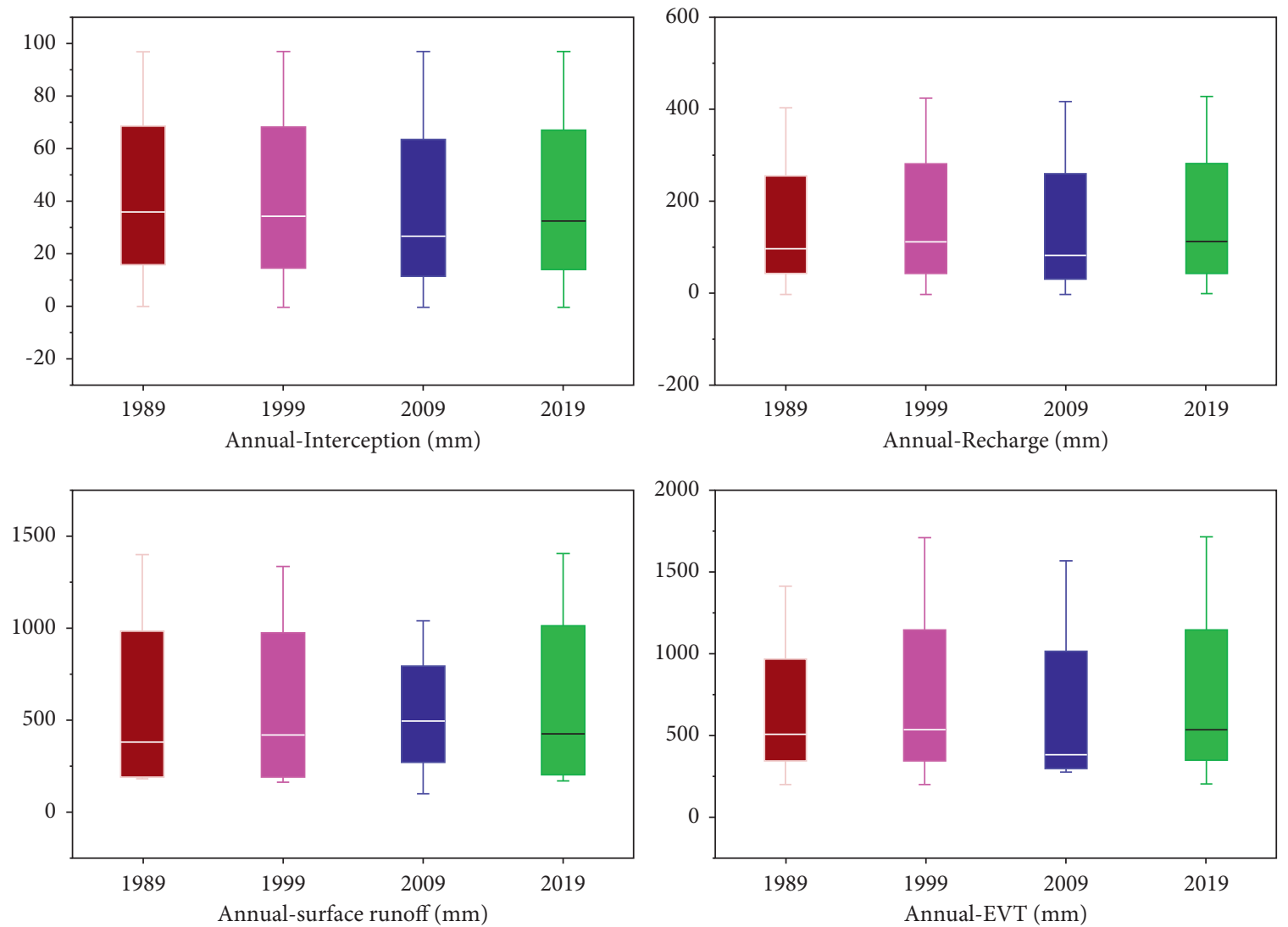

Figure 9: Long-term annual WetSpass-M simulated water balance components of the Bilate basin for LULC (1989, 1999, 2009, and 2019).

TAble 9: Long-term seasonal WetSpass-M simulated EVT (mm) for a LULC (1989, 1999, 2009, and 2019).

\begin{tabular}{lcccccccccccccccc}
\hline & \multicolumn{4}{c}{ Winter EVT } & \multicolumn{4}{c}{ Spring EVT } & \multicolumn{4}{c}{ Summer EVT } & \multicolumn{4}{c}{ Autumn EVT } \\
& 1989 & 1999 & 2009 & 2019 & 1989 & 1999 & 2009 & 2019 & 1989 & 1999 & 2009 & 2019 & 1989 & 1999 & 2009 & 2019 \\
\hline Min & 14.4 & 14.4 & 20.2 & 24.4 & 50 & 59.5 & 38.3 & 38.1 & 77.4 & 78.2 & 130.5 & 78.2 & 57.5 & 57.9 & 75.4 & 57.9 \\
Max & 953.6 & 943.7 & 987.1 & 1053.7 & 1022.9 & 972.1 & 1023 & 1023 & 825.6 & 824.8 & 755.8 & 824.8 & 918.6 & 918.8 & 896.7 & 918.8 \\
Mean & 62.4 & 76.7 & 75.6 & 105.4 & 150.4 & 157.8 & 175.1 & 179.3 & 236.6 & 240 & 225.1 & 278.4 & 133.5 & 148.3 & 136.1 & 146.5 \\
Stdv & 139.9 & 159.1 & 77.2 & 179.3 & 131.3 & 76.9 & 152.1 & 152.2 & 106.1 & 117 & 62.6 & 117.1 & 125.8 & 141.4 & 72.6 & 141.5 \\
\hline
\end{tabular}

surface runoff. The simulated results illustrated that the long-term minimum mean seasonal and maximum mean seasonal surface runoff was $13.3 \mathrm{~mm}$ in winter for the land use map of 1989 and $309.4 \mathrm{~mm}$ in summer for land use map of 2019, respectively, presented. Therefore, the study also demonstrated that the shrub lands and agricultural lands are more sensitive to the alteration of precipitation for balancing of transpiration and soil evaporation conditions.

3.3.5. Groundwater Recharge Characterization. The WetSpass-M model was implemented for four different land-use classes to predict the effects of landscape modifications on water balance components over the Bilate basin. The available 31 years of continuous daily meteorological data from 1988 to 2019 were fragmented into 4 seasons for which the Bilate basin is laid with bimodal climatic conditions. Therefore, this study predicted the long-term seasonal and annual groundwater recharge with continued modification of landscape dynamics. The determined winter and spring summer groundwater recharge was summarized as a minimum, maximum, and mean value for each season and annual base under each land use map. The minimum seasonal mean recharge is simulated in summer for land use maps of 2019. The annual mean minimum and maximum value of recharge was $117.5 \mathrm{~mm}$ and $147.1 \mathrm{~mm}$ for the land use map of 1989 and 2019, respectively (Figure 11(a) and Table 12). The seasonal minimum and maximum recharge was $1.2 \mathrm{~mm}$ in summer for land maps of 2009 and $50.9 \mathrm{~mm}$ in the winter season for land use map of 1989.

3.4. Long-Term Mean Seasonal Hydrologic Water Balance Components Change. WetSpass-M simulated results indicate that the hydrologic water balance component can be affected with landscape modification. Consequently, the 

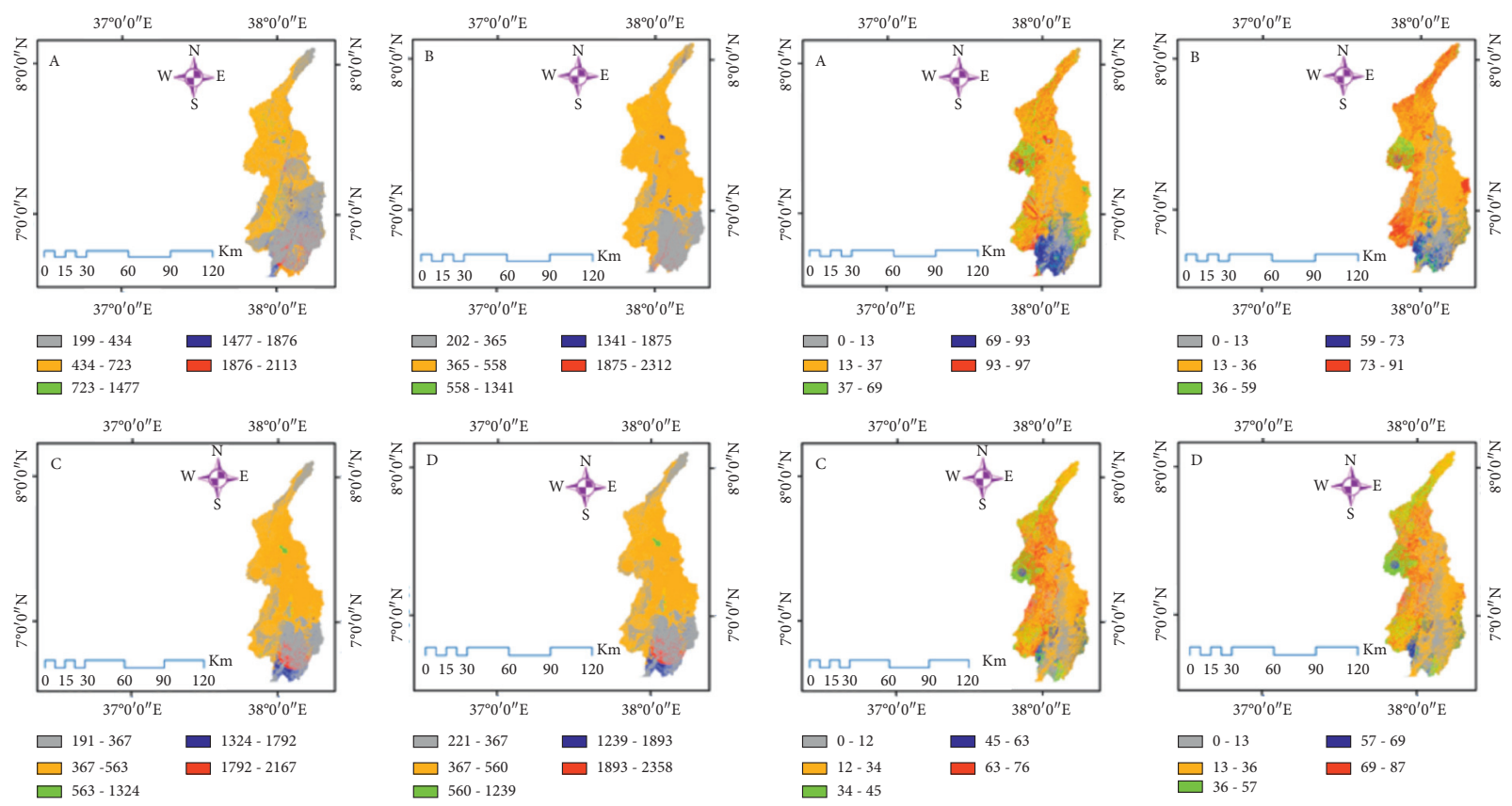

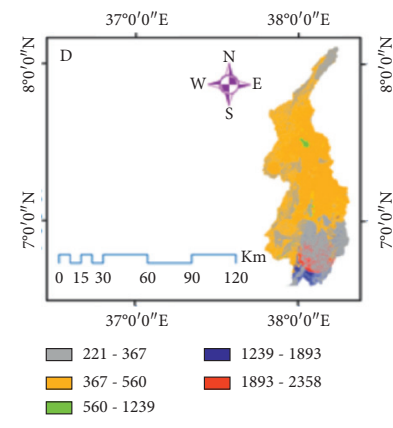

(a)
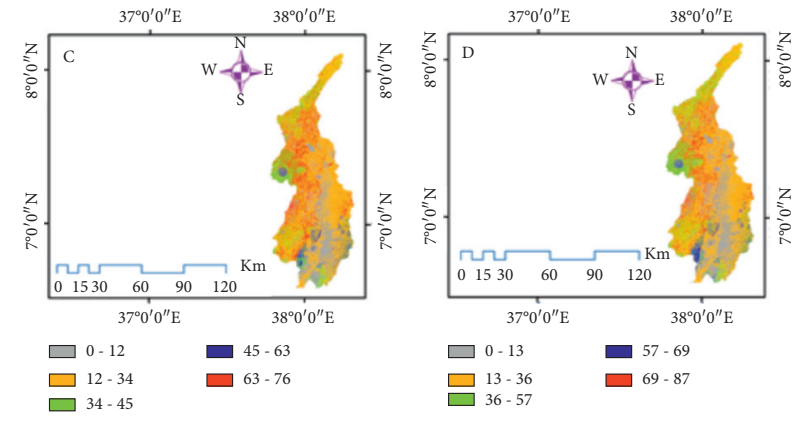

(b)

Figure 10: Maps of water balance components simulated with the WetSpass model (a) and (b) at each LULC classes of (A) 1989, (B) 1999, (C) 2009, and (D) 2019.

TABLe 10: Long-term seasonal WetSpass-M simulated interception (mm) of the Bilate basin for a LULC (1989, 1999, 2009, and 2019).

\begin{tabular}{|c|c|c|c|c|c|c|c|c|c|c|c|c|c|c|c|c|}
\hline & \multicolumn{4}{|c|}{ Winter interception } & \multicolumn{4}{|c|}{ Spring interception } & \multicolumn{4}{|c|}{ Summer interception } & \multicolumn{4}{|c|}{ Autumn interception } \\
\hline & 1989 & 1999 & 2009 & 2019 & 1989 & 1999 & 2009 & 2019 & 1989 & 1999 & 2009 & 2019 & 1989 & 1999 & 2009 & 2019 \\
\hline Min & 0.0 & 0.0 & & & 0 & 0 & 0 & 0 & 0.0 & & & 0 . & 0.0 & 0.0 & & 0.0 \\
\hline Max & 67.3 & 67.3 & 61.9 & 57.3 & 64.2 & 64.2 & 52.3 & 44.2 & 66.2 & 66.2 & 65 & 56 & 67.6 & 67 & 65 & 45.6 \\
\hline Mean & 19.3 & 19.0 & 16.7 & 11.8 & 26.4 & 25.9 & 19.7 & 14.0 & 27.3 & 26.8 & 20 & 17 & 25.1 & 24 & 19. & 16.8 \\
\hline Stdv & 13.2 & 13.0 & 11.9 & 9.7 & 19.5 & 18.6 & 13.3 & 13.1 & 20.4 & 19.5 & 15.5 & 12.0 & 18.4 & 17.7 & 14.7 & 11.2 \\
\hline
\end{tabular}

magnitude of interception has experienced decreasing trends with transformation and modification of landscapes in the Bilate basin. However, the amount of 31 years of interception changes is $12.38 \mathrm{~mm}$ which is the highest reduction from 1989 to 2019 . The determined investigation result highlights that there is an insignificant declination from (1989 to 1999) with below 1\% (Figure 12(a)). The annual average interception between 1989 and 2019 is decreased by $3.89 \mathrm{~mm}(10.68 \%)$ (Figure 13(c)). The investigated water balance simulation report indicated that the groundwater recharge is highly dependent on dynamics land use in the Bilate basin. According to the explored analysis, the changes in long-term seasonal groundwater recharge show a consistent reduction (Figure 12(b)). The simulated annual average groundwater recharge value in 31 years has decreased by $29.58 \mathrm{~mm}$ (23.22\%) of the annual average value (Figure 13(c)). The mean seasonal long-term surface runoff showed increase from $14.18 \mathrm{~mm}$ to $36.61 \mathrm{~mm}$ and $132.23 \mathrm{~mm}$ to $168.41 \mathrm{~mm}, 238.18 \mathrm{~mm}$ to $309.38 \mathrm{~mm}$, and $119.23 \mathrm{~mm}$ to $221.83 \mathrm{~mm}$ in winter, spring, summer, and autumn seasons, respectively, from 1989 to 2019. The averaged annual surface runoff for each LULC class was
$517.1 \mathrm{~mm}, 569.81 \mathrm{~mm}, 506.21 \mathrm{~mm}$, and $642.42 \mathrm{~mm}$ in 1989 , 1999, 2009, and 2019, respectively (Figure 13(a)).

The spatially distributed WetSpass-M hydrological model simulation shows that EVT increased from 1989 to 2019. The WetSpass-M model evaluates mean seasonally long-term EVT changes of the Bilate basin to be recorded maximum increment in the summer season from $3.4 \mathrm{~mm}$ to $41.85 \mathrm{~mm}$ from 1989 to 1999 and 1989 to 2019, respectively (Figure 12(d)). The average long-term annual EVT is estimated based on seasonally simulated data. Therefore, the determined averaged annual EVT values for each LULC classes are $499.89 \mathrm{~mm}$ (38.7\%), $517.68 \mathrm{~mm}$ (39\%), $455.7 \mathrm{~mm}$ (38\%), and $497.09 \mathrm{~mm}(38.43 \%)$ in 1989, 1999, 2009, and 2019, respectively (Figures 13(a) and 13(b)).

\section{Discussion}

4.1. Explored Impacts of LULC Transition on Hydrological Processes. In the Bilate basin of Ethiopia, due to the massive growth of the population [6], settlement and agricultural land showed noticeably increasing trends (Table 5 and Figures 10(a) and 10(b)). However, in the period of first 10 

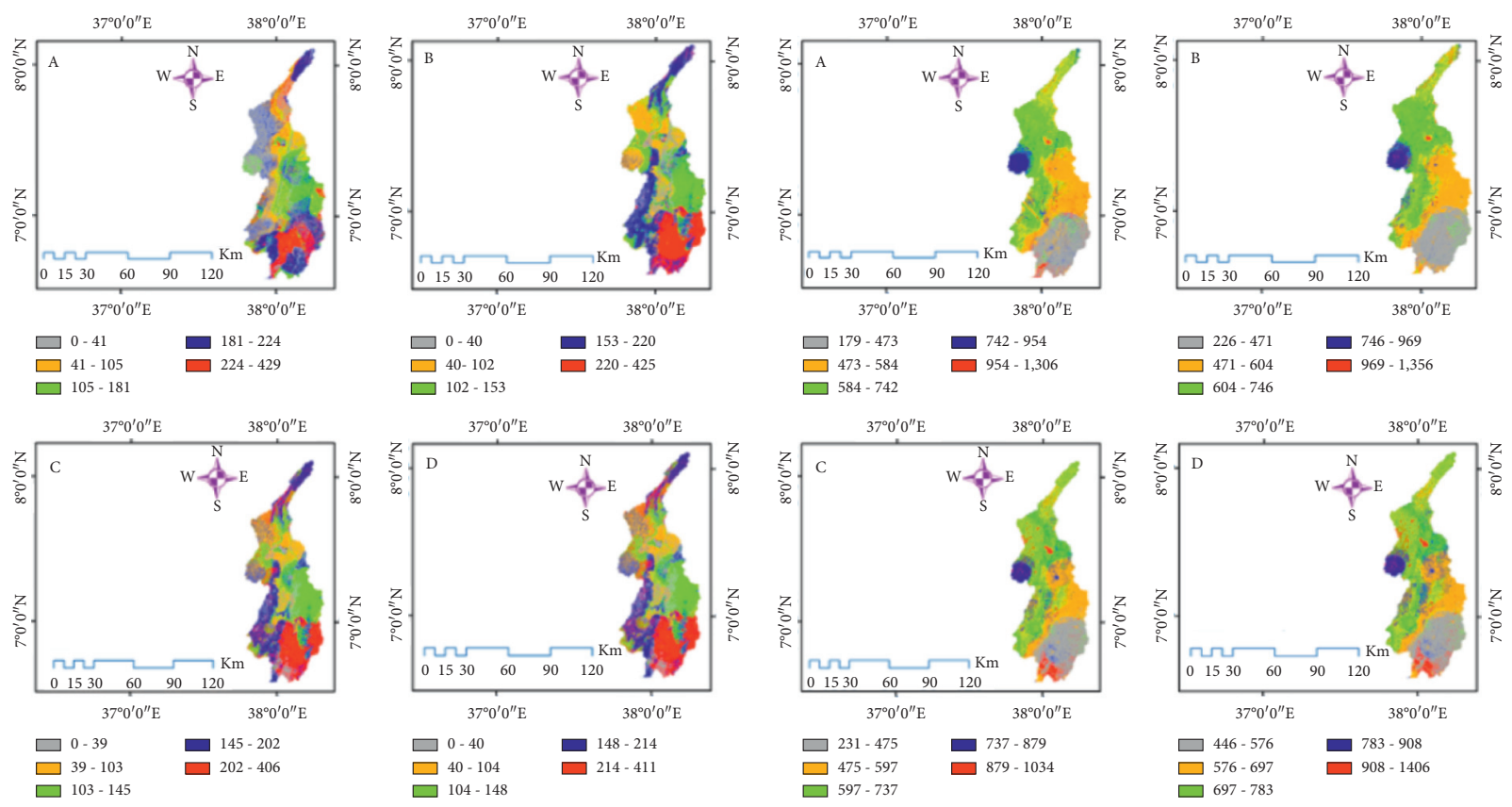

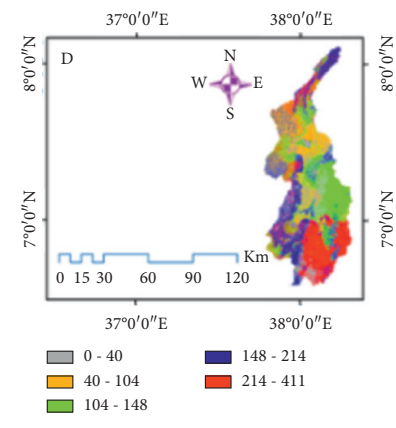

(a)
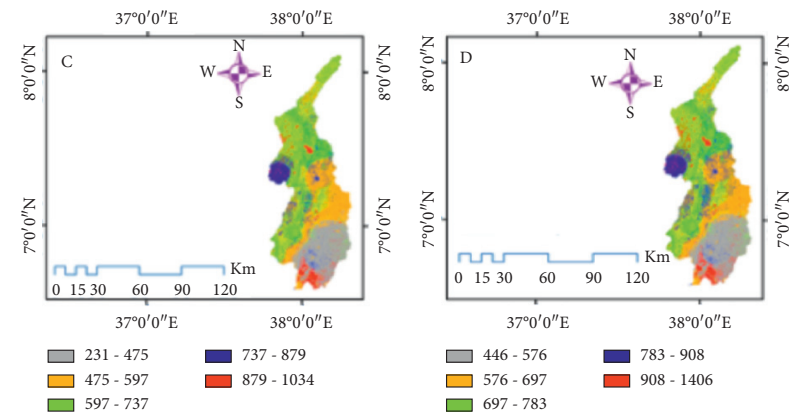

(b)

FIGURE 11: Maps of water balance components simulated with the WetSpass model (a) and (b) at each LULC classes of (A) 1989, (B) 1999, (C) 20011, and (D) 2019.

TABLE 11: Long-term seasonal WetSpass-M simulated surface runoff (mm) of the Bilate basin for a LULC (1989, 1999, 2009, and 2019).

\begin{tabular}{lcccccccccccccccc}
\hline & \multicolumn{3}{c}{ Winter surface runoff } & \multicolumn{4}{c}{ Spring surface runoff } & \multicolumn{4}{c}{ Summer surface runoff } & \multicolumn{4}{c}{ Autumn surface runoff } \\
& 1989 & 1999 & 2009 & 2019 & 1989 & 1999 & 2009 & 2019 & 1989 & 1999 & 2009 & 2019 & 1989 & 1999 & 2009 & 2019 \\
\hline Min & 0.3 & 0.5 & 1.4 & 0.5 & 13.9 & 9.6 & 28.3 & 10.6 & 92.4 & 107.6 & 90.1 & 147.6 & 17.4 & 62.7 & 56.8 & 122.7 \\
Max & 248.3 & 278.3 & 208.7 & 298.3 & 430.5 & 419.6 & 380.2 & 461.0 & 408.9 & 438.1 & 393.9 & 488.1 & 542.3 & 542.3 & 467.0 & 542.3 \\
Mean & 14.2 & 25.8 & 13.3 & 36.6 & 132.2 & 155.4 & 141.5 & 168.4 & 238.2 & 267.6 & 245.8 & 309.4 & 116.9 & 119.2 & 141.1 & 221.8 \\
Stdv & 20.0 & 21.8 & 11.2 & 32.1 & 44.1 & 51.3 & 39.0 & 76.0 & 87.4 & 92.5 & 79.6 & 163.0 & 64.4 & 74.5 & 51.8 & 120.2 \\
\hline
\end{tabular}

years (1989-1999), agricultural land and barren lands increased by $14.8 \%\left(801.6 \mathrm{~km}^{2}\right)$ and $6.77 \%\left(366.2 \mathrm{~km}^{2}\right)$, respectively, while grassland, forest, and shrub lands have decreased in the basin. According to the analysis, the increasing trends of agricultural land results show decreasing trends of the shrub, and grassland depicts that the shrub and grassland were converted to agricultural land during the assessed periods. Our investigation results are consistent with the previous findings which have been researched [59-69]. Moreover, the study established that expansion of agricultural land, degradation of forest, and bush lands facilitate high surface runoff rates in the basin since the total flow in a river from a basin is a function of surface runoff and subsurface flow that is equivalent to the long-term mean seasonal river discharge from the basin [58]. The summation of the subsurface flow and surface runoff simulated by the WetSpass model was implemented to calibrate the model with in situ observed streamflow data obtained from Bilate river gauge stations. The verified model result shows that the average minimum and maximum seasonal surface runoff in Bilate basin fluctuates from $13.3 \mathrm{~mm}$ to $309.4 \mathrm{~mm}$ in winter and summer in between (1989 to 2019), respectively. The thirty-one years' average minimum and maximum annual surface-runoff value ranges from $606.2 \mathrm{~mm}$ to $642.4 \mathrm{~mm}$ in winter and summer, respectively.

As presented in Figure 9, there are increasing trends in each seasonal and annual water balance component such as surface runoff and EVT, while groundwater recharge exhibits decreasing trends when time goes up. In Ethiopia, extreme meteorological drought was recorded 2008-2009 [58]. The results illustrate that there are changes in water balance components that decrease even though increasing amounts for LULC change during 2009. During this period, the average seasonal and annual water budget components such as interception, groundwater recharge, EVT, and surface runoff results were reduced compared to 1999 and 2019. Hence, simulation results were highly correlated with findings [21].

This study was mainly planned to investigate how water balance components in the basin are interrupted with ongoing landscape modification. Therefore, interception is one of the highly dependent components and has been affected through the modification of landscapes in the Bilate basin. Furthermore, the areas covered mostly 
TABLE 12: Long-term seasonal WetSpass-M simulated groundwater recharge (mm) of the Bilate basin for a LULC (1989, 1999, 2009, and 2019).

\begin{tabular}{lcccccccccccccccc}
\hline & \multicolumn{3}{c}{ Winter recharge } & \multicolumn{4}{c}{ Spring recharge } & \multicolumn{4}{c}{ Summer recharge } & \multicolumn{4}{c}{ Autumn recharge } \\
& 1989 & 1999 & 2009 & 2019 & 1989 & 1999 & 2009 & 2019 & 1989 & 1999 & 2009 & 2019 & 1989 & 1999 & 2009 & 2019 \\
\hline Min & 0 & 0 & 0 & 0 & 0 & 0 & 0 & 0 & 0 & 0 & 0 & 0 & 0 & 0 & 0 & 0 \\
Max & 101.99 & 129.75 & 114.29 & 129.75 & 151.08 & 165.65 & 145.16 & 165.65 & 139.96 & 141.91 & 92.5 & 141.91 & 128.97 & 156.01 & 147.95 & 156.01 \\
Mean & 50.89 & 48.16 & 43.82 & 38.63 & 40.81 & 41.36 & 34.41 & 32.48 & 9.06 & 9.21 & 1.16 & 6.12 & 45.03 & 40.03 & 33.09 & 31.56 \\
Stdv & 14.86 & 14.72 & 18.13 & 15.09 & 26.48 & 29.72 & 26.28 & 30.82 & 17.96 & 19.76 & 5.06 & 19.61 & 26.06 & 28.41 & 24.92 & 29.5 \\
\hline
\end{tabular}

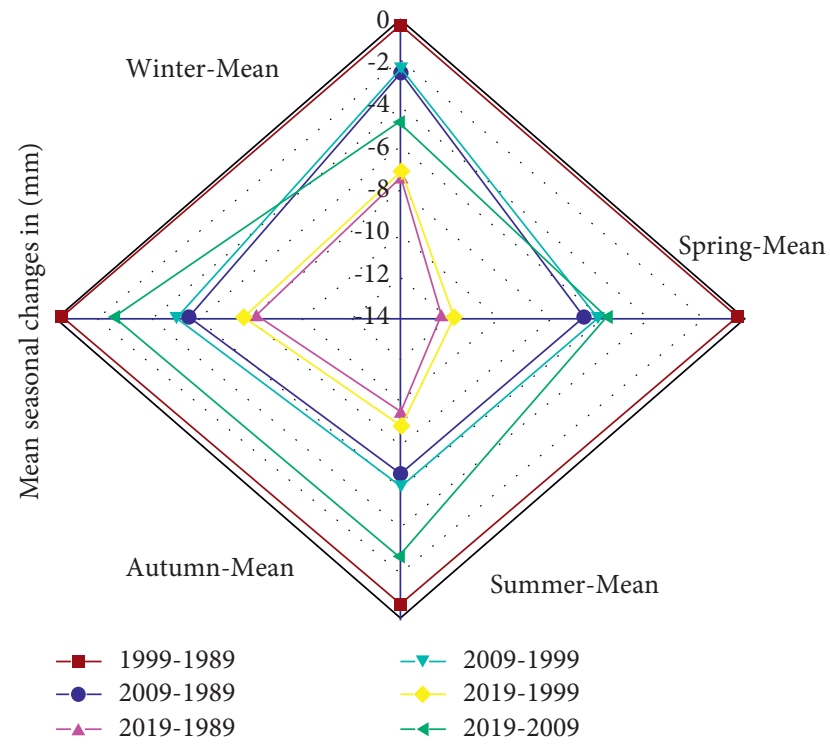

(a)

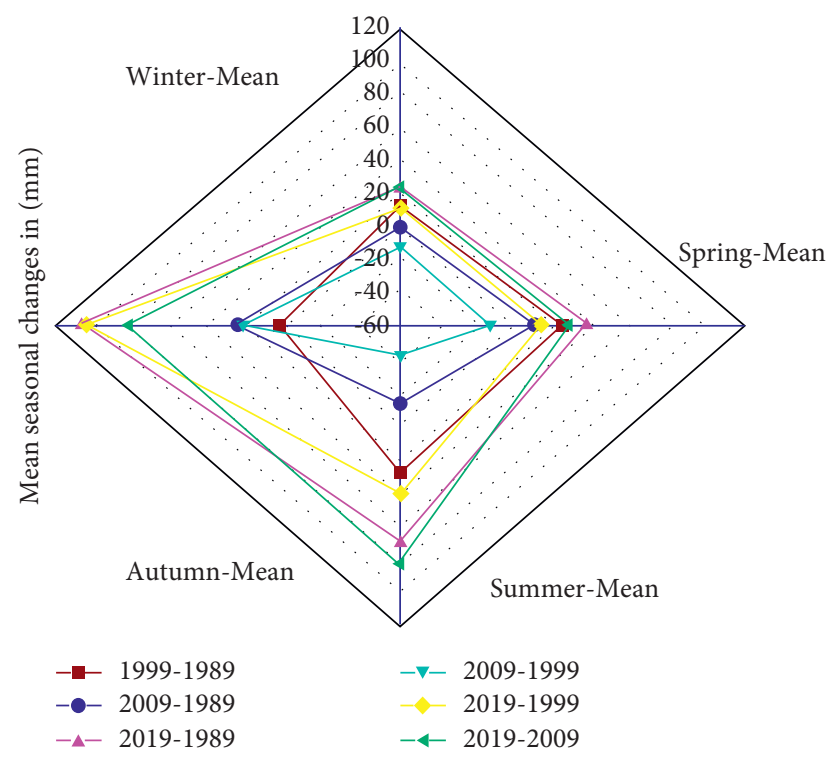

(c)

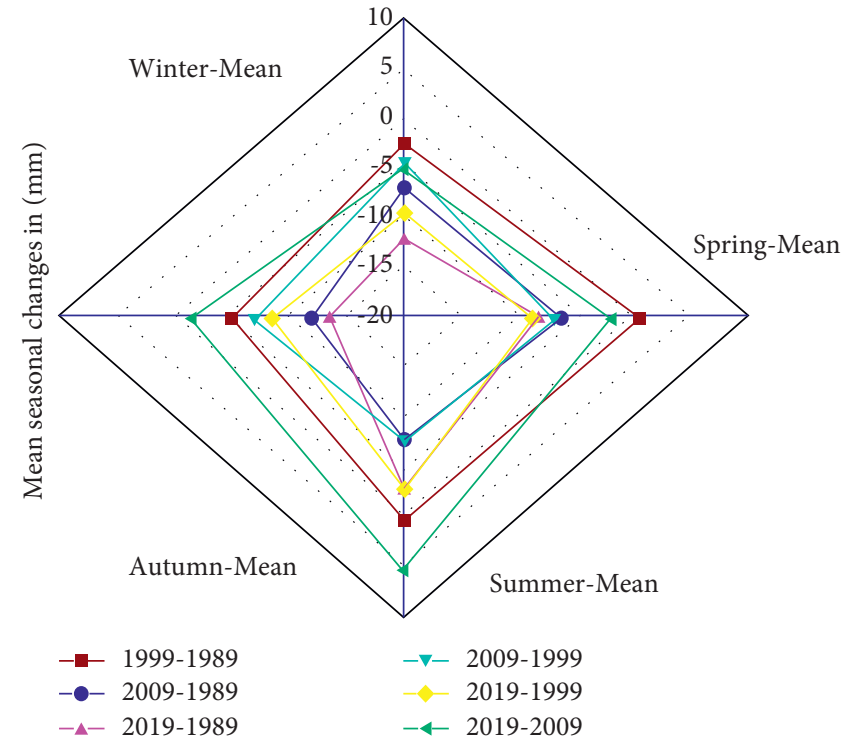

(b)

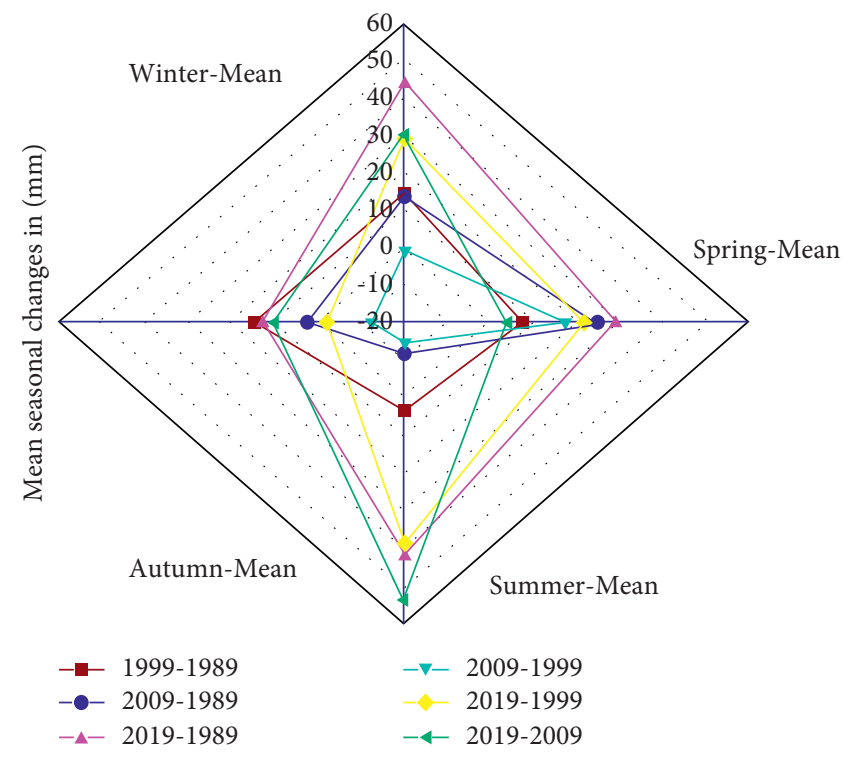

(d)

FIGURE 12: Long-term mean seasonal WetSpass simulated hydrologic water balance component changes of the Bilate basin for a LULC $(1989,1999,2009$, and 2019) where (a) mean seasonal interception changes in mm, (b) mean seasonal recharge changes in mm, (c) mean seasonal surface runoff changes in $\mathrm{mm}$, and (d) mean seasonal EVT changes in $\mathrm{mm}$.

by forest are intercepting more water than open vegetation such as grass and shrub (Figure 10(a)). Consequently, the investigation also shows that the shrublands and agricultural land are more sensitive to the alteration of precipitation for balancing transpiration and soil evaporation conditions. 


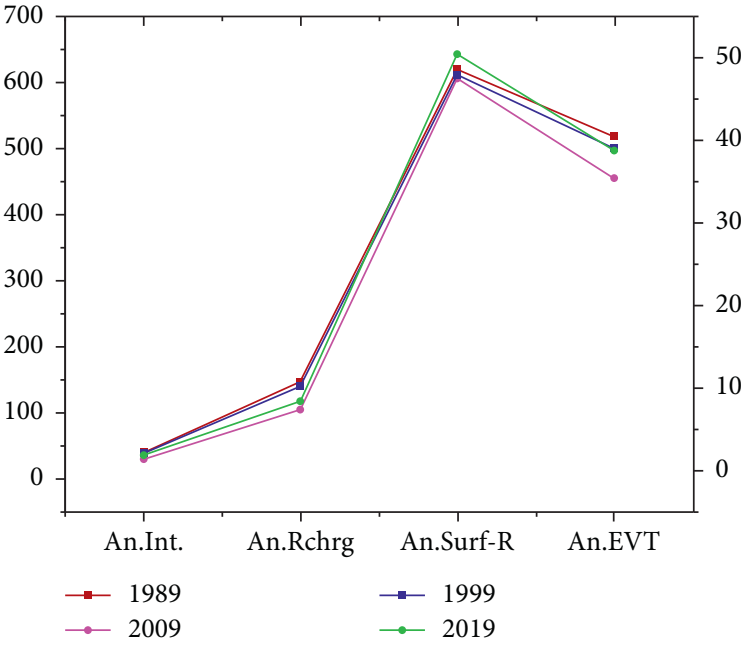

(a)

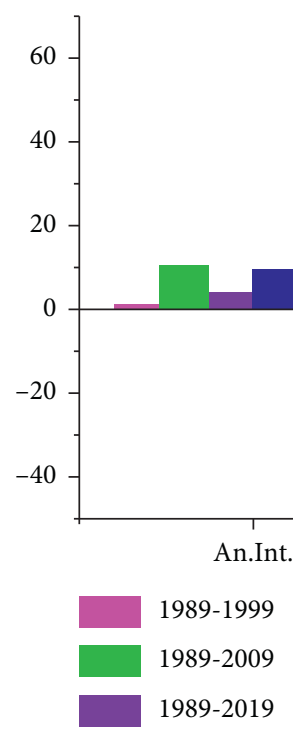

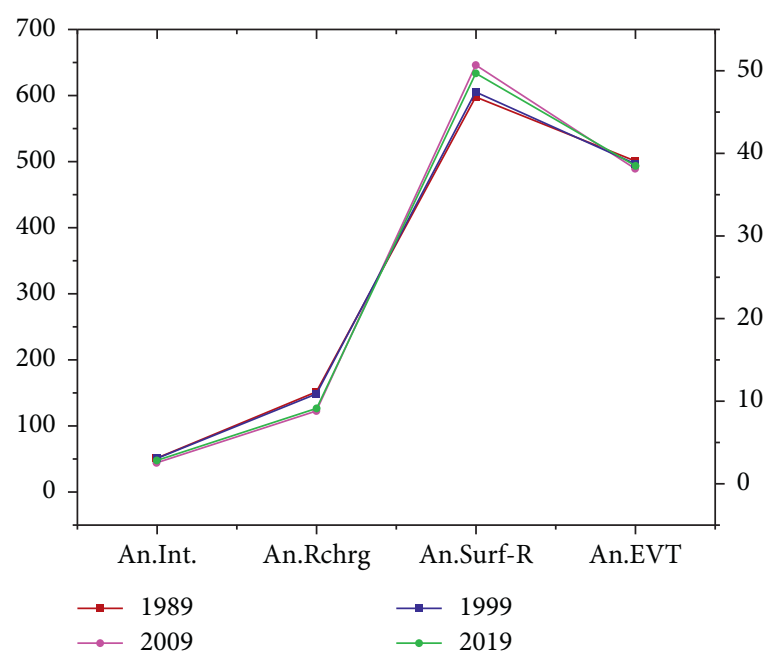

(b)

FIGURE 13: Mean annual water balance component. (a) Mean annual water balance component in (mm), (b) mean annual water balance component in (\%), and (c) mean annual water balance component changes $(\mathrm{mm})$ ) where An. Int = mean annual Interception, An. $\mathrm{Rchrg}=$ mean annual recharge, An. Surf-R= mean annual surface runoff, and An. EVT=mean annual evapotranspiration.

The examined conclusions showed that modification of landscapes specifically declining of forest, shrubland, and grassland with contrary increasing agricultural and built-up area affects the magnitude of surface runoff in the Bilate basin. The maximum mean seasonal surface-runoff change was recorded in autumn with an increment of $104.95 \mathrm{~mm}$ indicated in Figure 12(c). The average annual surface runoff is determined based on seasonally simulated data. According to our simulation, the annual average surface-runoff amount between 1989 and 2019 is increased by $125.05 \mathrm{~mm}(22.37 \%)$ of the annual average value shown in (Figure 13(c). These analysis results are aligned with the previous findings which have been researched around the world including Ethiopia $[64,70-72]$.

Actual evapotranspiration is one major component of hydrologic water balance components that highly affect groundwater recharge and surface runoff [72]. The annual average of EVT has increased by $97.2 \mathrm{~mm}(19.38 \%)$ of the simulated average annual value between 1989 and 2019 (Figure 13(c)). According to the analysis, the low annual evapotranspiration is experienced in northern, eastern parts, and most southern parts of the catchment which receive lower annual rainfall while high and moderately actual evapotranspiration value is practiced in central parts of the basin, specifically Lake Boyo area and north-western highland of the basin, because these regions are covered by cultivated crop, woodland, and occurrence of high rainfall in middle and north-western highland areas. In addition to these the Bilate river channel was also a source for actual evapotranspiration in the basin. Moreover, the magnitude of seasonal as well as average annual evapotranspiration of the Bilate basin fluctuates with rainfall and LULC modification. 
Therefore, the study concluded that precipitation and LULC are the main driving factors of actual evapotranspiration in the basin.

The previous investigation conducted by Dereje and Nedaw [14] and Molla et al. [73] have estimated groundwater recharge, EVT, and surface runoff using the WetSpass hydrological model in upper Bilate watershed and AbayaChamo basin. They have estimated the mean annual recharge of the catchment to be $9.4 \%$ of the total precipitation, while the direct surface runoff as only $20 \%$ of the total precipitation. Molla et al. [73] revealed that estimated annual amount of loss with EVT is $74.6 \%$ of total precipitation in the basin, while with surface runoff, it was $15.7 \%$, with groundwater recharge of only $9.7 \%$. Our present investigated results are not aligned with these findings. A few researchers [74] have revealed that the settlement and built-up areas have a tendency to generate a high volume of surface runoff within the region because they have substantially smaller amount vegetative area. Therefore, the study conducted by Dereje and Nedaw [14], and Molla et al. [73] have been ignored by the potential contributions of settlement and built-up area on hydrological processes during their evaluation, although the dynamics of urbanization is evidently ongoing in the basin. During the study, the potential impacts of settlement and the built-up area on surface and subsurface water were investigated, and the determined results experienced that surface runoff has been evidently affected by the degree of settlement and modification of urbanization in the Bilate basin. Beyond dynamics of LULC of the basin, hydrological parameters and water balance components always depend on the permeability of the soil, magnitude of the precipitation, and slope of the topography. In addition to that, groundwater is highly dependent on evapotranspiration. Therefore, mostly north-western and central-western of the Bilate basin are suitable for groundwater recharge. Meanwhile, the mountain front and plain surface are always suitable for groundwater recharge, and the lower part of the Bilate basin has experienced higher annual groundwater recharge. On the contrary, the eastern part of the basin reported a lower rate of annual and seasonal groundwater recharge that was attributed to the presence of shrub and grassland (Figure 11(a)). In general, the groundwater recharge analysis reveals that higher values are observed in forest land with permeable soils, as soil affects the process of groundwater recharge besides its effect on the other hydrologic processes. Moreover, soil systems principally disturb the magnitude of infiltration processes which ultimately influence the groundwater recharge in the area [75-77].

In order to assess the impacts of the anthropogenic and climatological factors on surface and subsurface water balance, topography is considered to be a critical input. This parameter is entered as raster layers, called Digital Elevation Models (DEMs), into WetSpass models to mathematically define the topography of a drainage area. This study has determined that the water balance of the study area is affected by the topography of the basin that was extracted from the DEM. The amount of recharge and surface runoff is evidently influenced by the resolution of the DEM in Bilate basin.

\section{Conclusions}

The enormous growth in population and continued landscape modification are root causes for hydrological water balance fluctuations in Bilate basin. The key factors of the LULC changes observed in the basin imply a decrease in the total amount of forest, shrubland, and natural grassland and a significant increase in agricultural land. These changes continuously alter the spatial patterns of the landscape and greatly modify the entire landscape of the basin. The driving factors for the modification of landscapes in the Bilate basin were both national and regional/ local in origin. Rapid population growth in semihumid and warm semiarid areas of the basin is a result of migration and policy change in the country which is considered the most important driving factor for modification of landscapes in the basin from 1989 to 2019 . LULC changes, and the related trend of increasing agricultural land expansion and reduction of natural vegetation in the basin, may lead to all-embracing changes in the surface and subsurface water flows.

The hydrologic water balance components in the Bilate basin were characterized by applying the WetSpass-M model, which is essential for integrated groundwater modelling of the Bilate basin and optimal long-term planning and management of the available water resources. The magnitude and spatial variability of groundwater recharge rely on climate conditions, groundwater depth, distributed land cover, soil texture, topography, and slope. Land cover is dominated by agricultural land while soil textures are dominated by sandy loam and loam in the Bilate basin. The WetSpass-M model estimates the annual EVT of the basin, for the period from 1989 to 2019. The comparison between in situ streamflow data from Bilate river gauging station and simulated WetSpass-M model indicates close agreement in groundwater recharge between the two model outputs with $R^{2}$ of 0.79 and 0.81 , while the root mean square errors (RMSEs) were 8.2 and $8.4 \mathrm{~mm}$ for 1989 and 2019, respectively. Moreover, the WetSpass-M model estimated the long-term average annual interception, groundwater recharge, surface runoff, and EVT were 36.4, 127.3, 614.9, and $517.6 \mathrm{~mm}$, respectively. The outputs of the WetSpass$\mathrm{M}$ model revealed a favourable structure of water balance in the Bilate basin, with the dominance of surface runoff. This study has achieved a useful milestone to contribute to the development of relevant management approaches for the basin.

\section{Data Availability}

Most of the data used in this research article are received from WIEE (Water, Irrigation, and Electricity of Ethiopia) and NMAE (National Meteorology Agency of Ethiopia).

\section{Conflicts of Interest}

The authors declare that there are no conflicts of interest regarding publication of this paper. 


\section{Acknowledgments}

The authors would like to thank all data providers, namely, WIEE (Water Irrigation and Electricity of Ethiopia) for providing the river flow data and NMAE (National Meteorology Agency of Ethiopia) for providing the climatic data. The authors are thankful to Arba Minch University who has provided all logistic support in conducting the research work.

\section{References}

[1] R. K. Adhikari, S. Mohanasundaram, and S. Shrestha, "Impacts of land-use changes on the groundwater recharge in the Ho Chi Minh city, Vietnam," Environmental Research, vol. 185, Article ID 109440, 2020.

[2] S. D. Derib, T. Assefa, B. Berhanu, and G. Zeleke, "Impacts of micro-basin water harvesting structures in improving vegetative cover in degraded hillslope areas of north-east Ethiopia," The Rangeland Journal, vol. 31, no. 2, pp. 259-265, 2009.

[3] S. B. Awulachew, A. D. Yilma, M. Loulseged, W. Loiskandl, M. Ayana, and T. Alamirew, Water Resources And Irrigation Development in Ethiopia, Colombo, Sri Lanka, International Water Management Institute (IWMI), Colombo, Sri Lanka, 2007.

[4] A. Getachew, "Rainwater harvesting in Ethiopia: an overview," in Proceedings of the Integrated Development for Water Supply and Sanitation: 25th WEDC Conference, pp. 387-390, Addis Ababa, Ethiopia, January 1999.

[5] R. DeFries and K. N. Eshleman, "Land-use change and hydrologic processes: a major focus for the future," Hydrological Processes, vol. 18, no. 11, pp. 2183-2186, 2004.

[6] K. Jinno, A. Tsutsumi, O. Alkaeed, S. Saita, and R. Berndtsson, "Effects of land-use change on groundwater recharge model parameters effects of land-use change on groundwater recharge model parameters," Hydrological Sciences Journal, vol. 54, p. 6667, 2009.

[7] S. B. Gebere, T. Alamirew, B. J. Merkel, and A. M. Melesse, Land Use and Land Cover Change Impact on Groundwater Recharge: The Case of Lake Haramaya Watershed, Ethiopia, Springer, Berlin, Germany, 2016.

[8] W. Yin, L. Hu, M. Zhang, J. Wang, and S. C. Han, "Statistical downscaling of GRACE-derived groundwater storage using ET data in the north China plain," Journal of Geophysical Research: Atmosphere, vol. 123, no. 11, pp. 5973-5987, 2018.

[9] J. S. Famiglietti, M. Lo, S. L. Ho et al., "Satellites measure recent rates of groundwater depletion in California's central valley," Geophysical Research Letters, vol. 38, no. 3, pp. 2-5, 2011.

[10] K. K. Abdelaziz, Y. Nicaise, L. Séguis et al., "Influence of land use land cover change on groundwater recharge in the continental terminal area of Abidjan, ivory coast," Journal of Water Resource and Protection, vol. 12, no. 5, pp. 431-453, 2020.

[11] T. A. Ansari, Y. B. Katpatal, and A. D. Vasudeo, "Spatial evaluation of impacts of increase in impervious surface area on SCS-CN and runoff in Nagpur urban watersheds, India," Arabian Journal of Geosciences, vol. 9, no. 18, 2016.

[12] J. Panthi, P. Dahal, M. L. Shrestha et al., "Spatial and temporal variability of rainfall in the Gandaki river basin of Nepal Himalaya," Climate, vol. 3, no. 1, pp. 210-226, 2015.

[13] M. Mathewos, M. Dananto, T. Erkossa, and G. Mulugeta, "Land use land cover dynamics at Bilate Alaba sub-watershed, southern Ethiopia," Journal of Applied Sciences \& Environmental Management, vol. 23, no. 8, p. 1521, 2019.

[14] B. Dereje and D. Nedaw, "Groundwater recharge estimation using WetSpass modeling in upper bilate," Momona Ethiopian Journal of Science, vol. 11, no. 1, pp. 37-51, 2018.

[15] B. R. Scanlon, R. W. Healy, and P. G. Cook, "Choosing appropriate techniques for quantifying groundwater recharge," Hydrogeology Journal, vol. 10, no. 1, pp. 18-39, 2002.

[16] Z. M. Wang, O. Batelaan, and F. De Smedt, "A distributed model for water and energy transfer between soil, plants and atmosphere (WetSpa)," Physics and Chemistry of the Earth, vol. 21, no. 3, pp. 189-193, 1996.

[17] A. M. Armanuos, A. Negm, and C. Yoshimura, "Application of WetSpass model to estimate groundwater recharge variability in the nile delta aquifer," Arabian Journal of Geosciences, vol. 9, 2016.

[18] E. Meresa and G. Taye, "Estimation of groundwater recharge using GIS-based wetSpass model for Birki watershed, the eastern zone of Tigray, northern Ethiopia," Sustainable Water Resources Management, vol. 5, no. 4, pp. 1555-1566, 2019a.

[19] E. Tigray, E. Meresa, A. Girmay, and A. Gebremedhin, "Water balance estimation using integrated GIS- based WetSpass model in the Birki watershed," Physical Science International Journal, vol. 22, no. 3, pp. 1-17, 2019.

[20] K. Walraevens, I. Vandecasteele, K. Martens et al., "Groundwater recharge and flow in a small mountain catchment in northern Ethiopia," Hydrological Sciences Journal, vol. 54, no. 4, pp. 739-753, 2009.

[21] M. Haji, D. Wang, L. Li, D. Qin, and Y. Guo, "Geochemical evolution of fluoride and implication for $\mathrm{f}$-enrichment in groundwater : example from the Bilate river basin of southern main Ethiopian rift," Water, vol. 10, pp. 1-20, 2018.

[22] B. Hussen, A. Mekonnen, and S. M. Pingale, "Integrated water resources management under climate change scenarios in the sub-basin of Abaya-Chamo, Ethiopia," Modeling Earth Systems and Environment, vol. 4, no. 1, pp. 221-240, 2018.

[23] O. Batelaan and F. D. E. Smedt, "WetSpass: a flexible, GIS based, distributed recharge methodology for regional groundwater modelling," Groundwater, vol. 269, pp. 11-17, 2001.

[24] E. M. Ampe, I. Vanhamel, E. Salvadore et al., "Impact of urban land-cover classification on groundwater recharge uncertainty," IEEE Journal of Selected Topics in Applied Earth Observations and Remote Sensing, vol. 5, no. 6, pp. 1859-1867, 2012.

[25] C. McSweeney, M. New, G. Lizcano, and X. Lu, "The UNDP climate change country profiles," Bulletin of the American Meteorological Society, vol. 91, no. 2, pp. 157-166, 2010.

[26] C. Jarosław and O. Batelaan, "Application of the WetSpa distributed hydrological model for catchment with significant contribution of organic soil," Annals of Warsaw University of Life Sciences-SGGW Land Reclamation, vol. 43, 2011.

[27] P. M. Nyenje and O. Batelaan, "Estimating the effects of climate change on groundwater recharge and baseflow in the upper Ssezibwa catchment, Uganda," Hydrological Sciences Journal, vol. 54, no. 4, pp. 713-726, 2009.

[28] S. T. Woldeamlak, O. Batelaan, and F. De Smedt, "Effects of climate change on the groundwater system in the Grote-Nete catchment, Belgium," Hydrogeology Journal, vol. 15, no. 5, pp. 891-901, 2007.

[29] A. Yenehun, K. Walraevens, and O. Batelaan, "Spatial and temporal variability of groundwater recharge in Geba basin, northern Ethiopia," Journal of African Earth Sciences, vol. 134, pp. 198-212, 2017. 
[30] K. G. Hubbard, "Spatial variability of daily weather variables in the high plains of the USA," Agricultural and Forest Meteorology, vol. 68, no. 1-2, pp. 29-41, 1994.

[31] P. Gao, P. Li, B. Zhao et al., "Use of double mass curves in hydrologic benefit evaluations," Hydrological Processes, vol. 31, pp. 4639-4646, 2017.

[32] C. F. Merriam, A Comprehensive Study Of The Rainfall On The Susquehanna Valley, Transactions, American Geophysical Union, Hoboken, NJ, USA, 1937.

[33] Y. Guo, Y. Zhang, L. Zhang, and Z. Wang, "Regionalization of hydrological modeling for predicting streamflow in ungauged catchments: a comprehensive review," Wiley Interdisciplinary Reviews: Water, vol. 8, no. 1, pp. 1-32, 2021.

[34] R. Arsenault, M. Breton-Dufour, A. Poulin, G. Dallaire, and R. Romero-Lopez, "Streamflow prediction in ungauged basins: analysis of regionalization methods in a hydrologically heterogeneous region of Mexico," Hydrological Sciences Journal, vol. 64, no. 11, pp. 1297-1311, 2019.

[35] X. Jin, C. Xu, Q. Zhang, and Y. David, "Regionalization study of a conceptual hydrological model in Dongjiang basin, south China," Quaternary International, vol. 208, no. 1-2, pp. 129-137, 2009.

[36] R. Merz, "Regionalisation of catchment model parameters," Journal of Hydrology, vol. 287, pp. 95-123, 2004.

[37] L. Oudin, V. Andre, C. Perrin, and C. Michel, "Spatial proximity, physical similarity, regression and ungaged catchments: a comparison of regionalization approaches based on 913 French catchments," Water Resources Research, vol. 44, pp. 1-15, 2008.

[38] S. Narbondo, A. Gorgoglione, M. Crisci, and C. Chreties, "Enhancing physical similarity approach to predict runoff in ungauged watersheds in sub-tropical regions," Water, vol. 12, no. 2, pp. 2003-2012, 2020.

[39] L. Samaniego, "Streamflow prediction in ungauged catchments using copula-based dissimilarity measures," Water Resources Research, vol. 46, 2010.

[40] J. Samuel, P. Coulibaly, M. Asce, and R. A. Metcalfe, "Estimation of continuous streamflow in Ontario ungauged basins: comparison of regionalization methods," Journal of Hydrologic Engineering, vol. 16, pp. 447-459, 2011.

[41] S. Li, L. Tong, F. Li, L. Zhang, B. Zhang, and S. Kang, "Variability in energy partitioning and resistance parameters for a vineyard in northwest China," Agricultural Water Management, vol. 96, pp. 955-962, 2009.

[42] J. Parajka, R. Merz, and G. Bl, "Sciences a comparison of regionalisation methods for catchment model parameters," Hydrology and Earth System Sciences, vol. 9, pp. 157-171, 2005.

[43] A. Y. Jillo, S. S. Demissie, A. Viglione, D. H. Asfaw, and M. Sivapalan, "Characterization of regional variability of seasonal water balance within Omo-Ghibe river basin, Ethiopia," Hydrological Sciences Journal, vol. 62, no. 8, pp. 1200-1215, 2017.

[44] B. F. Ochoa-Tocachi, W. Buytaert, and B. De Bièvre, "Regionalization of land-use impacts on streamflow using a network of paired catchments," Water Resources Research, vol. 52, no. 9, pp. 6710-6729, 2016.

[45] S. Visessri and N. McIntyre, "Regionalisation of hydrological responses under land-use change and variable data quality," Hydrological Sciences Journal, vol. 61, no. 2, pp. 302-320, 2016.

[46] A. R. Young, V. Keller, and J. I. M. Griffiths, "Predicting low flows in ungauged basins: a hydrological response unit approach to continuous simulation," Gioscience, vol. 308, pp. 134-138, 2006.
[47] G. Tegegne, D. K. Park, and Y. O. Kim, "Comparison of hydrological models for the assessment of water resources in a data-scarce region, the upper Blue Nile river basin," Journal of Hydrology: Regional Studies, vol. 14, pp. 49-66, 2017.

[48] C. Prieto, N. Le Vine, D. Kavetski, E. García, and R. Medina, "Flow prediction in ungauged catchments using probabilistic random forests regionalization and new statistical adequacy tests," Water Resources Research, vol. 55, no. 5, pp. 4364-4392, 2019.

[49] J. B. Campbell, Introduction to Remote Sensing, The Guilford Press, New York, NY, USA, 4th edition, 2007.

[50] R. G. Congalton, "A review of assessing the accuracy of classifications of remotely sensed data," Remote Sensing of Environment, vol. 37, no. 1, pp. 35-46, 1991.

[51] J. R. Jensen, Introductory Digital Image Processing: A Remote Sensing Perspective, Pearson Prentice Hall, Upper Saddle River, NJ, USA, 3rd edition, 2005.

[52] J. Cohen, "A coefficient of agreement for nominal scales," Educational and Psychological Measurement, vol. 20, no. 1, pp. 37-46, 1960.

[53] F. Nachtergaele, H. van Velthuizen, and L. Verelst, The Harmonized World Soil Database. Verson 1.0, FAO, Rome, Italy, 2010, http://library.wur.nl/WebQuery/wurpubs/ fulltext/154132.

[54] K. Abdollahi, A. Bazargan, and G. McKay, "Water balance models in environmental modeling," in Handbook of Environmental Materials Management, C. Hussain, Ed., Springer, Berlin, Germany, 2018.

[55] FAO, "The state of the food and agriculture," FAO Agriculture, vol. 38, 2007.

[56] B. G. L. Hargreaves, A. M. Asce, G. H. Hargreaves, F. Asce, J. P. Riley, and M. Asce, "Irrigation water requirements for Senegal river basin," Journal of Irrigation and Drainage Engineering, vol. 111, no. 3, pp. 265-275, 1986.

[57] R. G. Allen, L. S. Pereira, D. Raes, M. Smith, and W. Ab, Fao,1998. Irrigation and Drainage Paper No. 56, FAO, Rome, Italy, 1998.

[58] K. Abdollahi, I. Bashir, B. Verbeiren et al., "A distributed monthly water balance model: formulation and application on Black Volta basin," Environmental Earth Sciences, vol. 76, no. 5, 2017.

[59] M. S. Aduah, G. P. W. Jewitt, and M. L. W. Toucher, "Assessing impacts of land use changes on the hydrology of a lowland rainforest catchment in Ghana, west Africa," Water, vol. 10, no. 1, 2017.

[60] M. Belihu, S. Tekleab, B. Abate, and W. Bewket, "Hydrologic response to land use land cover change in the upper gidabo watershed, rift valley lakes basin, Ethiopia," HydroResearch, vol. 3, pp. 85-94, 2020.

[61] A. W. Galata, "Analysis of land use/land cover changes and their causes using landsat data in hangar watershed, Abay basin, Ethiopia," Journal of Sedimentary Environments, vol. 5, no. 4, pp. 415-423, 2020.

[62] A. C. Guzha, "Regional studies impacts of land use and land cover change on surface runoff, discharge and low flows: evidence from east Africa," Journal of Hydrology, vol. 15, pp. 49-67, 2018.

[63] S. Hu, Y. Fan, and T. Zhang, "Assessing the effect of land use change on surface runoff in a rapidly urbanized city: a case study of the central area of Beijing," Land, vol. 9, no. 1, pp. 1-15, 2020.

[64] S. H. Mahmoud and A. A. Alazba, "Hydrological response to land cover changes and human activities in arid regions using 
a geographic information system and remote sensing," PLoS One, vol. 10, pp. 1-19, 2015.

[65] A. Negese, "Impacts of land use and land cover change on soil erosion and hydrological responses in Ethiopia," Applied and Environmental Soil Science, vol. 2021, Article ID 6669438, 17 pages, 2021.

[66] M. Tadese, L. Kumar, R. Koech, and B. K. Kogo, "Remote sensing Applications: society and environment mapping of land-use/land-cover changes and its dynamics in awash river basin using remote sensing and GIS," Remote Sensing Applications: Society and Environment, vol. 19, Article ID 100352, 2020.

[67] D. Tewabe and T. Fentahun, "Assessing land use and land cover change detection using remote sensing in the Lake Tana basin, northwest Ethiopia," Cogent Environmental Science, vol. 6 , no. 1, 2020.

[68] S. Twisa and M. F. Buchroithner, "Land-use and land-cover (LULC) change detection in Wami river basin, Tanzania," Land, vol. 8, 2019.

[69] A. K. Yimer, A. T. Haile, S. D. Hatiye, and A. Gedle, "Seasonal effect on the accuracy of land use/land cover classification in the bilate sub-basin," Abaya-Chamo Basin, Rift valley Lakes Basin of Ethiopia, vol. 3, 2021.

[70] C. Hailu, S. Tamene, A. Demissie, and F. Gudu, "Surface runoff modeling in Ketar watershed, Ethiopia," Journal of Sedimentary Environments, vol. 5, no. 1, pp. 151-162, 2020.

[71] V. M. Kattsov, J. E. Walsh, W. L. Chapman, V. A. Govorkova, T. V. Pavlova, and X. Zhang, "Simulation and projection of Arctic freshwater budget components by the IPCC AR4 global climate models," Journal of Hydrometeorology, vol. 8, no. 3, pp. 571-589, 2007.

[72] A. Salem and M. El-rawy, "Assessment of groundwater recharge, evaporation, and runoff in the Drava basin in Hungary with the WetSpass model," Hydrology, vol. 6, 2019.

[73] D. D. Molla, T. A. Tegaye, and C. G. Fletcher, "Simulated surface and shallow groundwater resources in the AbayaChamo lake basin, Ethiopia using a spatially-distributed water balance model," Journal of Hydrology: Regional Studies, vol. 24, Article ID 100615, 2019.

[74] C. Xu, M. Rahman, D. Haase, Y. Wu, M. Su, and S. Pauleit, "Surface runoff in urban areas: the role of residential cover and urban growth form," Journal of Cleaner Production, vol. 262, Article ID 121421, 2020.

[75] K. G. Berhanu and S. D. Hatiye, "Identification of groundwater potential zones using proxy data: case study of megech watershed, Ethiopia," Journal of Hydrology: Regional Studies, vol. 28, 2020.

[76] P. Kumar, S. Herath, R. Avtar, and K. Takeuchi, "Mapping of groundwater potential zones in Killinochi area, Sri Lanka, using GIS and remote sensing techniques," Sustainable Water Resources Management, vol. 2, no. 4, pp. 419-430, 2016.

[77] E. Rukundo and A. Doğan, "Dominant influencing factors of groundwater recharge spatial patterns in Ergene river catchment, Turkey," Water, vol. 11, no. 4, 2019. 